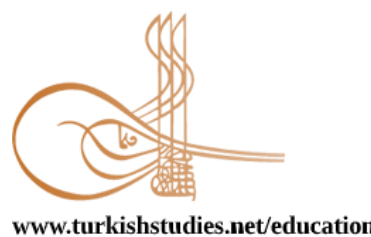

Turkish Studies - Educational Sciences

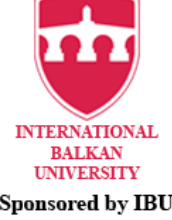

Research Article / Araștırma Makalesi

\title{
Din ve Değerler Eğitimi Açısından Majid Majidi’nin Filmleri Üzerine Bir İnceleme (“Hz. Muhammed: Allah'ın Elçisi” Filmi Örneği)*
}

\author{
An Examination on Majid Majidi's Movies in Terms of Religious and Values Education \\ ("Muhammad: The Messenger of God" As an Example of Movie)
}

\author{
İsmail Acar ${ }^{* *}$ - Ahmet Ali Çanakc1***
}

\begin{abstract}
In this study, Iranian director and screenwriter Majid Majidi's "Muhammed: The Messenger of God" movie, is aimed to be examined in terms of religious-value education. In this context, the life and works of Majidi are briefly discussed. The messages he wanted to convey with the concepts of religious-value in the movie called 'Muhammad: The Messenger of God', which had an impact on world cinemas and the Islamic world, were tried to be revealed. In the study, qualitative research design was adopted and literature review and document review methods were used. In this context, the literature on the subject has been scanned, the documents have been examined, and the findings of similar researches have been used. The findings were evaluated in the light of the literature. According to the results reached in the study; in the movie of 'Muhammed: The Messenger of God', it is seen that Muhammad's (pbuh) childhood period is detailed, and the events and his religious-value concepts are depicted by considering the conditions of the Arabian Peninsula. However, the understanding of religious-value education in Islamic society and the background of the transformation that took place in this process was also revealed. In addition, in terms of religious and values education, with the messages given over the movie, which has a rich content, the emphasis is placed on religious-value concepts such as; faith, worship, Qur'anic verses, religious characters, religious places, religious names, religious clothes, behaviors that express value, fate, salutation, generosity, tolerance, truthfulness, altruism / conscience, humility, kindness, love, compassion, mercy, courtesy, responsibility, trust, patience, justice, sharing, honesty, loyalty, diligence, sensitivity and self-sacrifice. It can be said that this makes the movie remarkable on an international scale and creates awareness in the informal-centered religious-value education of the society.
\end{abstract}

Structured Abstract: Introduction: In recent years, it is understood that the mass media has developed at an unprecedented pace in human history and encompasses all of humanity. The influence of cinema is also great in the rapid transmission of this interaction and communication (Tinaz Gürmez, 2006; Monaco, 2009; Yorulmaz, 2010). Cinema has an important power in human and social life. Creating a sense of reality on

\footnotetext{
* Bu çalışma, İsmail Acar'ın "Din ve Değerler Eğitimi Açısından İran Sineması: Mejid Mejidi'nin Filmleri Örneği” başlıklı yüksek lisans tezinden türetilmiştir.

** Din Kültürü ve Ahlak Bilgisi Öğretmeni

Teacher of Religious Culture and Ethics Knowledge

ORCID 0000-0001-6307-358X

i.acar35@hotmail.com

*** Dr. Öğr. Üyesi, Balıkesir Üniversitesi, İlahiyat Fakültesi, Felsefe ve Din Bilimleri Bölümü Asst. Prof. Dr. Balikesir University, Faculty of Theology, Department of Philosophy and Religious Sciences ORCID 0000-0001-6200-2763

aa_canakci@yahoo.com

Cite as/ Atıf: Acar, İ. \& Çanakcı, A. A. (2020). Din ve değerler eğitimi açısından Majid Majidi’nin filmleri üzerine bir inceleme ("Hz. Muhammed: Allah'ın elçisi” filmi örneği). Turkish Studies - Education, 15(4), 2317-2341. https://dx.doi.org/10.47423/TurkishStudies.43697

Received/Geliş: 19 May/Mayıs 2020

Accepted/Kabul: 27 August/Ağustos 2020

Copyright (C) INTAC LTD, Turkey
} 
people with its visuality, cinema can direct people's attitudes and behaviors (Yorulmaz, 2010, p. 80; Güçhan, 1993; Monaco, 2009).

In this context, cinema is also important in a platform where a message or perception can be delivered quickly and effectively (Aksu, 2004). Besides, cinema; is influenced by the social, cultural, economic, political, religious, moral and educational life of the geography where it is located in (Sarmış, 2016; Yaghmoorala, 2013). It plays an important role in the transformation of the psycho-social life of the society in general, and the families' psycho-social life in particular, and the education of religion-morality-values. Although this transformation may cause the transfer of social values in a positive and sometimes negative way, it also brings some problems with it. In this context, problematic issues arise such as whether the concepts (religion, value, etc.) transferred from the cinema scene are transferred correctly, how the cinema uses and emphasizes these concepts (Yorulmaz, 2010; Yorulmaz, 2016; Sarmış, 2016). For this reason, it is important to examine and investigate the effects of religious-value education concepts both nationally and internationally through cinema.

Regarding religious-value education, especially "Muhammad: The Messenger of God"; constituting universal values based on the films of the Iranian director Majid Majidi, who came to the forefront in the world with the movie; It is important to reveal how concepts such as religion, value and religion-value education are reflected in order to better understand the subject. For this reason, the subject of our study has been determined as Majid Majidi's Movies in Terms of Religious and Values Education ("Muhammad: The Messenger of God" As an Example of Movie). Accordingly, the main problem of the study is that "Majid Majidi 'Muhammad: The Messenger of God' it is to determine how the film can be handled in terms of religion and values education."

Purpose: In this study, it is aimed to reveal how the messages that are intended to be given in Majid Majidi's films are given over the concepts of religion and values education. Another purpose of the study is to determine the situation regarding values such as the worship, belief, Qur'anic verses, religious characters, religious places, religious names, religious clothes, expressions of value, behaviors that express values, fate, , salutation, generosity, tolerance, truthfulness, altruism / conscience, modesty, kindness, love, affection, compassion, kindness, responsibility, trust, patience, justice, sharing, honesty, loyalty, diligence, hospitality, sensitivity and self-sacrifice and to examine how these are conveyed.

The following research questions will be addressed within the framework of these main objectives:

1. What are the sub-messages to emphasize in terms of religion and value education in the movie "Muhammad: The Messenger of God"?

2. What are the shapes, figures and expressions used on religious elements and values in the movie "Muhammad: The Messenger of God"?

3. How to make religious emphasis in the movie "Muhammad: The Messenger of God"?

4. How can we evaluate the film "Muhammad: The Messenger of God" in terms of religion and values education?

Method: Qualitative research design was adopted in the study. In this context, literature review and document review methods were used (Özkan, 2019; Yıldırım \& Şimşek, 2004). In the study, content analysis, one of the qualitative research techniques (Balc1, 2006), was used to evaluate the obtained documents and findings (Fraenkel \& Wallen, 2009; Patton, 2018; Yıldırım \& Şimşek, 2004). In this context, 19 films directed by Majid Majidi, one of the leading names of Iranian cinema, were watched for a total of 1592 minutes. "Muhammad: The Messenger of God", which is one of the Majidi films in which concepts related to education of religion and values are intensely covered in its visual content and which has a high viewer score especially in IMDb (IMDB, t.y.a), was selected and examined.

The sections of the prominent scenes related to religion and values examined in the film are given below the pictures and in the text, by indicating the time (hour / minute) in parentheses. In addition, these concepts are classified as a framework of religion and values and shown in a table. Descriptive analysis technique was used to reach this result (Yıldırım \& Şimşek, 2004).

Result: Cinema has been an entertainment tool since its early years; it has also served as a means of expression, a mirror of reality, a branch of art, and a propaganda device. While serving all these practices, he has turned into his object by dealing with an event, a person, a problem, a crisis, a separation or a reality. In 
this process, events centered on religious-value education that are important in the psycho-social development of individuals and society from time to time become the object of cinema. Accordingly, cinema, which has come to the forefront in informal-centered transfer of religion-values, influences individuals and societies with the messages that he wants to convey in films.

In this context, it is shown how the values such as cooperation, sharing, halal-haram balance, honesty, conscience, brotherhood, patience prevent negative feelings and thoughts such as hatred, jealousy, selfishness in Majidi's movie "Muhammad: The Messenger of God".

It can be said that the importance of the concepts of religion-value was emphasized and awareness was created in general Islam, in particular the Prophet Muhammad (pbuh), in the framework of worship, belief, Quranic verses, religious characters, religious places, religious names, religious clothes, value expressions, values expressing behavior, destiny, values; by demonstrating the values of salutation, generosity, tolerance, truthfulness, altruism, humility, kindness, love, affection, compassion, kindness, responsibility, trust, patience, justice, sharing, honesty, loyalty, diligence, hospitality, sensitivity and self-sacrifice With this study in which life of the Prophet Muhammad (pbuh) is discussed in detail in terms of religious-value education with the messages / sub-messages on the cinema in religious framework. In addition, it can be stated that the Prophet Muhammad's (pbuh) mercy and compassion aspect is examined with universal values

In terms of religion and values education, it is seen that the movie "Muhammad: The Messenger of God" has a very rich content of values. In this context, humans continue to take shape according to their developmental stages from the moment of birth. The first environment where religion and values are processed is the family, then the social environment. As it enters human life, another factor that significantly affects its shaping emerges as technology. Cinema, one of the mass media, outshines other media in terms of reaching the masses. Therefore, it is emphasized that people's orientation and shaping towards the good, true and beautiful, and the rapid and effective spread of religion and values within the society can be effectively done through cinema.

It can be said that the presence of cinema in the Islamic world and the emergence of such works have contributed significantly to explaining religion and values. The use of the cinema sector, which strengthens the hand in an instrumental sense, by a Muslim, who also has a duty, should be seen as a necessity of the age. On the other hand, it can be stated that emphasizing the positive effects of the films shot in the Islamic world on universal values is important in terms of contributing to the informal education of religion and values.

In addition, it can be said that the research has contributed to the field in terms of introducing Prophet Muhammad (pbuh) in the conditions of his time, transferring his life and experiences, values, to today's young generations, and especially revealing the understanding of religion and values in the Islamic society and the transformation that took place in this process.

Keywords: Religious Education, Value, Education, The Prophet Muhammad, Majid Majidi, Iranian Cinema.

Öz: Bu çalışmada, İranlı yönetmen ve senarist Majid Majidi’nin “Hz. Muhammed: Allah'ın Elçisi” adlı filminin din-değer eğitimi açısından incelenmesi amaçlanmıştır. Bu kapsamda, Majidi’nin kısaca hayatı ve eserleri ele alınmış, dünya sinemalarında ve İslam dünyasında etki uyandıran “Hz. Muhammed: Allah'ın Elçisi" adlı filminde yer alan dini-değer içerikli kavramlarla vermek istediği mesajlar ortaya konulmaya çalışılmıştır. Çalışmada, nitel araştırma deseni benimsenmiş, literatür taraması ve doküman incelemesi yöntemleri kullanılmıştır. Bu bağlamda, konuyla ilgili literatür taranmış, ulaşılan dokümanlar incelenerek konuyla alakalı gerçekleştirilen benzer araştırmaların bulgularından yararlanılmıştır. Ulaşılan bulgular literatür 1şı̆̆ında değerlendirilmiştir. Çalışmada ulaşılan sonuçlara göre; "Hz. Muhammed: Allah'ın Elçisi” filminde, Hz. Muhammed (sav)'in çocukluk dönemine ayrıntılı olarak yer verildiği, başından geçen olayların ve sahip olduğu din-değer kavramlarının Arap yarımadasının şartları da göz önünde bulundurularak betimlendiği görülmektedir. Bununla birlikte İslam toplumunda din-değer eğitimi anlayışının ve bu süreçte gerçekleşen dönüşümün arka planının da ortaya konulduğu söylenebilir. Ayrıca din ve değerler eğitimi açısından, zengin bir içeriğe sahip olan film üzerinden verilen mesajlarla; inanç, ibadet, Kur'an ayetleri, dini karakterler, dini mekânlar, dini isimler, dini kıyafetler, değer ifade eden davranışlar, kader, selamlaşma, cömertlik, hoşgörü, doğruluk, diğerkâmlık/îsâr, tevazu, iyilik, sevgi, şefkat, merhamet, nezaket, sorumluluk, emanet, sabır, adalet, paylaşım, dürüstlük, sadakat, çalışkanlık, duyarlılık ve fedakârlık gibi dini-değer kavramlarına vurgu 
yapılmasının, filmi uluslararası ölçekte dikkat çekici hale getirdiği ve toplumun informal merkezli din-değer eğitiminde farkındalık oluşturduğu söylenebilir.

Anahtar Kelimeler: Din Eğitimi, Değer, Eğitim, Hz. Muhammed, Majid Majidi, İran Sineması

\section{Giriş}

\section{Konu ve Problem}

Son yıllarda kitle iletişim araçlarının insanlık tarihinde görülmemiş bir hızla gelişim gösterdiği ve tüm insanlığg kuşattığı anlaşılmaktadır. Bu etkileşim ve iletişimin bu şekilde hızlı aktarılmasında sinemanın ${ }^{1}$ etkisi de büyüktür (bkz. Tınaz Gürmez, 2006; Monaco, 2009; Yorulmaz, 2010). Sinema, insan ve toplum hayatında önemli bir güce sahiptir. Görsellikleri ile insanlar üzerinde gerçeklik duygusu uyandıran sinema, kişilerin tutum ve davranışlarını yönlendirebilmektedir. İnsanların giyim-kuşamlarını ve dünyaya bakışlarını etkileyebilmekte hatta bazı insanları şiddete sevk edebilmektedir (Yorulmaz, 2010, s. 80; Güçhan, 1993; Monaco, 2009).

Bu bağlamda sinema, günümüzde verilmek istenen bir mesajın veya algının hızlıca ve etkili şekilde verilebileceği bir düzlem olması açısından da önemlidir (bkz. Aksu, 2004). Bunun yanında sinema; genelde evrensel, özelde ise bulunduğu coğrafyanın sosyal, kültürel, ekonomik, siyasi, dini, ahlaki ve eğitsel hayatından etkilenmekte (bkz. Sarmış, 2016; Yaghmoorala, 2013) ve genelde toplumun, özelde ise ailelerin psiko-sosyal hayatının ve din-ahlak-değer eğitiminin dönüşümünde önemli rol oynamaktadır. Bu dönüşüm, bazen olumlu bazen olumsuz yönde toplum değerlerinin transferine sebebiyet verebilmekle birlikte, beraberinde birtakım problemleri de getirmektedir. $\mathrm{Bu}$ çerçevede sinema sahnesinden insanlara aktarılan kavramların (din, değer vb.) doğru aktarılıp aktarılmaması, sinemanın bu kavramları nasıl kullandığı, nasıl vurguladığı gibi sorunsallar ortaya çıkmaktadır (bkz. Yorulmaz, 2010; Yorulmaz, 2016; Sarmış, 2016). Bu yüzden din-değer eğitimi kavramlarının sinema aracılığıyla gerek ulusal gerekse uluslararası ölçekteki etkisinin ele alınması ve araştırılması önemlidir

Din-değer eğitimi² ile ilgili özellikle “Hz. Muhammed: Allah'ın Elçisi” filmiyle dünyada ön plana çıkan İranlı yönetmen Majid Majidi’nin fimlerinden hareketle evrensel değerleri oluşturan; din, değer ve din-değer eğitimi gibi kavramların nasıl yansıtıldığını ortaya koymak, konunun daha iyi anlaşılması bakımından önem arz etmektedir. Bu süreçte sinema sahnesinden insanlara transfer edilen bu kavramların doğru aktarılıp aktarılmaması, sinemanın bu kavramları nasıl kullandığı, nasıl vurguladığı gibi problemler ortaya çıkabilmektedir. Yukarıda bahsedilen kavramların transferi noktasında sinemanın incelenmesi ve öncelenmesi elzemdir. Bu nedenle çalışmamızın konusu "Din ve Değerler Eğitimi Açısından Majid Majidi’nin Fimleri (Hz. Muhammed: Allah'ın Elçisi Filmi Örneği)" olarak belirlenmiştir. Buna bağlı olarak çalışmanın temel problemi ise, "Majid Majidi'nin 'Hz. Muhammed: Allah'ın Elçisi' adlı filminin din ve değerler eğitimi açısından nasıl ele alınabileceğini belirlemektir.”

\section{Amaç}

$\mathrm{Bu}$ araştırmada, Majid Majidi'nin filmlerinde verilmek istenen mesajların din ve değerler eğitimi kavramları üzerinden nasıl verildiğinin ortaya konulması amaçlanmıştır. Çalışmanın bir başka amacı ise filmlerin içeriğindeki ibadet, inanç, Kur'an ayetleri, dini karakterler, dini mekânlar,

\footnotetext{
${ }^{1}$ Sinema ve sinemanın etkileri ile ilgili ayrıntılı bilgi için bkz. Onaran, 1986; Erdoğan, 1992; Rotha, 1996; Abisel, 1999; Bazın, 2000; Nowell Smith, 2003; Abisel, 2003; Batur, 2005; Lüleci, 2007; Özön, 2008; Vincenti, 2008; Kale, 2010; Teksoy, 2014; Yorulmaz, 2016; Sarmış, 2016.

${ }^{2}$ Din-değer eğitimi ile ayrıntılı bilgi için bkz. Bilgin, 1990; Yavuz, 1988; Peker, 1998; Öcal, 1999; Acuner, 2005; Kara, 2006; Bahçekapıl1, 2011; Hökelekli, 2013a; Hökelekli, 2013b; Hökekli, 2015; Aydın, 2014; Köylü \& Altaş, 2014; Meydan, 2014; Türk, 2014; Tosun, 2015; Ulusoy \& Dilmaç, 2015; Bahçekapı11, 2017; Köylü \& Oruç, 2017; Doğan \& Ege, 2017; Aydin, 2017.
}

Turkish Studies - Education, 15(4) 
dini isimler, dini kıyafetler, değer ifadeleri, değer ifade eden davranışlar, kader, selamlaşma, cömertlik, hoşgörü, doğruluk, diğerkâmlık/îsâr, tevazu, iyilik, sevgi, şefkat, merhamet, nezaket, sorumluluk, emanet, sabır, adalet, paylaşım, dürüstlük, sadakat, çalışkanlık, konukseverlik, duyarlılık ve fedakârlık gibi değerler ile ilgili bir durum tespiti yaparak bunların ne şekilde aktarıldığını incelemektir.

$\mathrm{Bu}$ temel amaçlar çerçevesinde ele alınacak olan aşağıdaki araştırma sorularına yanıt bulunmaya çalışılacaktır:

1. “Hz. Muhammed: Allah'ın Elçisi” filminde din ve değer eğitimi açısından vurgulamak istenen alt mesajlar ${ }^{3}$ nelerdir?

2. “Hz. Muhammed: Allah'ın Elçisi” filminde dini ögeler ve değerler üzerinde kullanılan şekil, figür ve ifadeler nelerdir?

3. "Hz. Muhammed: Allahın Elçisi” filminde dini vurgular nasıl yapılmaktır?

4. "Hz. Muhammed: Allahın Elçisi" filmi din ve değerler eğitimi açısından nasıl değerlendirebilir?

\section{3. Önem}

Sinema, insan ve toplumun sosyo-kültürel gelişimi üzerinde büyük bir etkiye sahiptir. (bkz. Güçhan, 1993; Ryan ve Kellner, 1997; Aksu, 2004; Monaco 2009; Yorulmaz, 2010; Yorulmaz, 2016) Toplumu yavaş ama etkili ve kalıcı bir şekilde yönlendirir. Sinemada filmler; gazete, dergi, kitap gibi yayınlardan çok daha fazla sayıda kişiye ulaşarak mesajını geniş kitlelere iletebilmektedir. Ayrıca benzer mesajları uzun süre aynı kitlelere ilettiği için uzun vadede etkili ve kalıcı izler bırakabilmektedir. Sinemanın insan ve toplum üzerindeki bu büyük etki gücü, onu zaman zaman dindeğer eğitimi açısından hem büyük bir araç, hem de büyük bir tehlike olarak ortaya koymaktadır. (bkz. Yorulmaz, 2010, s.80; Aksu, 2004; Sarmış, 2016).

Din ve değer kavramları, salt bilgi üzerinden incelenecek kavramlar olmayıp, yaşamın içinden, hatta yaşamı şekillendirme konusunda önemli rolü olan kavramlardır. Dolayısıyla bu kavramlar, çağımızın en hızlı ve etkili iletişim aracı olan sinema alanında filmlerde kullanımlarıyla insanın zihin dünyasında ciddi etkileşimler yapmakta ve bu durum gün geçtikçe daha önemli bir hale gelmektedir. (bkz. Sarmış 2016; Yorulmaz, 2010; Yorulmaz, 2016; Türkeri, 2019)

Günümüzde eğitim materyali olarak görsel medya kullanımı gün geçtikçe artmakta, bilgi süreçleri de bu sürece dâhil olmaktadır. Din ve değerlerin verildiği filmlerin sayısındaki artış, bu iki kavrama yüklenilen olumlu-olumsuz etkileri de beraberinde getirmektedir. Özellikle eğitim sürecinde kullanılacak filmlerin yorumlanması ve etkilerinin detaylı bir şekilde araştırmaya tabi tutulması konusundaki çalışmaların azlığı, bu alanın önemini sürekli arttırmaktadır.

Bu bakımdan sinemanın/filmlerin insan ve toplum üzerindeki etkisi iyi analiz edilmeli ve din-değer eğitimine yardımcı bir vasıta olarak kullanılmasının yolları aranmalıdır (Yorulmaz, 2010, s. 80). Bununla ilgili uluslararası alanda son yıllarda ön plana çıkan İranlı yönetmen Majid Majidi’nin din-değer eğitimiyle ilgili filmleri dikkat çekmektedir. Yapım yılı 2015 olan "Hz. Muhammed: Allah'ın Elçisi" adlı filmiyle bunu ortaya koyduğu söylenebilir. Ancak bu süreçte filmlerin din-değer eğitimi açısından değerlendirildiği akademik çalışmaların ise sınırlı düzeyde olduğu anlaşılmaktadır Dolayısıyla bu çalışmanın, belirtilen ihtiyacın giderilmesine, bundan sonra yapılacak araştırmalara ve literatüre katkı sağlaması beklenmektedir.

Öte yandan 'Hz. İsa'yı anlatan 200'e yakın film, Hz. Musa'yı anlatan 80'e yakın film, Buda'y1 anlatan 40’a yakın filmin (sinema sektöründe) çekildiği görülmektedir

\footnotetext{
3 "Filmlerin arka planına yerleştirilerek seyirciye verilmek istenen mesaj” (Sarmış, 2016, s. 13).
} 
(https://www.haberler.com/iranli-yonetmen-majidi-filmde-hz-muhammed-in-3695922-haberi/, 2019). Ünlü tarihçi Michael Hart (Hart, t.y.) yazdığ 1 "Tarihte En Önemli Yüz Kişi” adlı kitabında birinci sırasına Hz. Muhammed'i (Alpsoy, 2012) koymasına rağmen film sektöründe din ve değerler açısından toplumu iyiye, güzele, doğruya ve adaletli olana yönlendiren Hz. Muhammed için sadece iki film çekilmiştir. Bu durumun da araştırmanın önemini bir kez daha ortaya koyduğu söylenebilir.

\section{Yöntem}

Çalışmada nitel araştırma deseni benimsenmiştir. Bu çerçevede literatür taraması ve doküman incelemesi yöntemlerinden yararlanılmıştır. Literatür taraması, araştırma yapılan konu ile ilgili daha önce yapılmış çalışmaları incelemeyi esas alan bir yöntemdir. Bu yöntem, söz konusu problem hakkında ne yapıldığının görülmesini sağlayarak, araştırmacıya bu konu hakkında yol haritası çizmeye yardım etme noktasında oldukça önemlidir. Literatür taraması, öncelikle ilk kaynağa ulaşma hedefiyle birlikte eğer birincil kaynaklara ulaşmak mümkün değilse, ikincil kaynaklar üzerinden gerçekleşen bir tarama yöntemidir. (Balc1, 2006). Doküman incelemesi ise, araştırılması amaçlanan olgular hakkında bilgi içeren yazılı materyallerin analizini kapsamaktadır (Yıldırım \& Şimşek, 2004). Bu materyaller, yazılı olabileceği gibi çalışma konusu ile ilgili film, video ve fotoğraflar (görüntü temelli/ses temelli/görsel-işitsel temelli) şeklinde de olabilir. Bunlar çalışmanın problemine göre belirlenir. Bu süreçte sadece dokümanların açıklaması yapılmaz, dokümanlarla verilmek istenilen mesajların incelenmesi ve ortaya konulması da sağlanır (Özkan, 2019; Yıldırım \& Şimşek, 2004; Dora, 2020; Başa, 2020).

Yapılan literatür taraması ve doküman incelemesi sonucu ulaş1lan, Yaren'in (2002): "Devrim Sonrası İran Sineması Muhsin Mahmelbaf Örneği"; Batur'un (2005): "Siyasal İslam Sinemas1 Örneği İran Sineması"; Lüleci'nin (2007) "Sinema ve Din Türk Sineması Örneği”; Furat'1n (2008) "Yetişkinlerin Yaygın Din Eğitiminde Televizyonun Yeri ve Fonksiyonları (İstanbul Örneği)", Özgökbel Bilis'in (2011) “Çizgi Filmlerde Temsil Edilen Toplumsal Değerler Sistemi”, Yorulmaz'ın (2016): "Sinema ve Din Eğimi” ve Sarmış’ın (2016) "Sinema ve Din (Sekülerleşme Bağlamında Hollywood Sineması Örneği)" adlı araştırmalar, bu çalışmaya bir bakış açısı ve katkı sağlamıştır.

Çalışmada, ulaşılan dokümanların ve bulguların değerlendirilmesinde, nitel araştırma tekniklerinden (Balcı, 2006, s. 57) biri olan içerik analizinden faydalanılmıştır. İçerik analizi, yazılı veya görsel/işitsel dokümanların derinlemesine incelenmesine ve değerlendirilmesine katkı sağlayan etkili bir tekniktir (bkz. Fraenkel \& Wallen, 2009; Patton, 2018; Yıldırım \& Şimşek, 2004, https://www.academia.edu/19689098/9-NITEL-ANALIZLER-ICERIK-VE-BETIMSEL-ANALIZ, 2020). Bu kapsamda filmdeki metinler arasında geçen her türlü din ve değerlerle ilgili görsel ve işitsel argümanlar tespit edilerek, onların analizlerinin yapılması hedeflenmiştir. Bu süreçte gerekli verilere ulaşmak için; sinema alanında yapılmış akademik çalışmaları yüzeysel bir bakış açısıyla ele alıp, belli başlı çalışmalar üzerinden problem, amaç, yöntem ve sonuç açısından inceleme yapılmıştır.

Özellikle araştırma, İran sineması alanında yapılan çalışmaların sınırlı olmasından dolayı çalışmanın ele alınışı ağırlıklı olarak içerik analizi ve veri toplama yöntemlerinden olan "görsel inceleme" üzerinden gerçekleşmiştir. Görsel inceleme/araştırma yöntemi ${ }^{4}$, filmlerin defalarca izlenmesini mümkün kılmakta ve böylece kapsamlı verilere ulaşmaya olanak tanımaktadır.

Araştırmada konu ile ilgili literatür, din ve değerler dikkate alınarak değerlendirilmiştir. İzlenen filmdeki din ve değerler ile ilgili ön plana çıkan sahnelere ait kesitlere, parantez içerisinde zamanı (saat/dk.) da belirtilerek resimlerin altında ve metin içerisinde yer verilmiştir. Ayrıca bu kavramlar, din ve değerler çerçevesi şeklinde sınıflandırılarak tablo halinde gösterilmiştir. Bu sonuca ulaşabilmek için betimsel analiz tekniği kullanılmıştır. Bu teknik, var olmuş ya da var olan bir durumu herhangi bir değişikliğe uğratmaksızın olduğu gibi betimlemeyi/tasvir etmeyi sağlamaktadır

\footnotetext{
${ }^{4}$ Görsel araştırma yöntemleri ile ilgili ayrıntılı bilgi için bkz. Bedir Erişti, 2018.
} 
(bkz. Y1ldırım \& Şimşek, 2004; https://www.academia.edu/19689098/9-NITEL-ANALIZLERICERIK-VE-BETIMSEL-ANALIZ, 2020).

Veri toplama yöntemlerinden olan görsel inceleme ile İran sinemasının önde gelen isimlerinden Majid Majidi’nin ${ }^{5}$ yönetmenliğini yaptığı 19 film, toplamda 1592 dakika izlenerek incelemiştir. Majidi'nin filmleri içerisinde alan uzmanlarının da görüşü alınarak görsel içeriğinde din ve değerler eğitimiyle ilgili kavramların yoğun olarak ele alındığ t.y.a) izleyici puanı yüksek filmlerden biri olan "Hz. Muhammed: Allah'ın Elçisi” adlı film seçilerek hem metinsel, hem de görsel açıdan incelemiştir.

\section{Kapsam ve Sinırlılıklar}

Araştırmanın kapsamı, İran sinemasının önde gelen yönetmenlerinden Majid Majidi'nin "Hz. Muhammed: Allah'ın Elçisi” adlı filminin din-değer eğitimi açısından incelemesi olduğu için, diğer ülkelerdeki sinemalar (Hollywood, Bollywood vb.) ve Majid Majidi’nin diğer filmlerinin değerlendirilmesini ele almamaktadır. Dolayısıyla çalışma, konu açısından Majidi'nin "Hz. Muhammed: Allah'ın Elçisi" adlı filmi ile sınırlıdır. Film analizinde ele alınacak olan din ve değerlerin evrensel ve kültürel anlamda tamamının incelenmesi araştırmanın sınırlılıklarını aşacağından, bunların seçimi konusunda bir sınırlamaya gidilmiştir. Bu bağlamda araştırma; alan uzmanlarının görüşleri doğrultusunda din-değer eğitiminde ön plana çıkan (dini çerçeve) ibadet, inanç, Kur'an ayetleri, dini karakterler, dini mekânlar, dini isimler, dini kıyafetler, değer ifadeleri, değer ifade eden davranışlar, kader; (değerler çerçevesi) selamlaşma, cömertlik, hoşgörü, doğruluk, diğergamlık/îsâr, tevazu, iyilik, sevgi, şefkat, merhamet, nezaket, sorumluluk, emanet, sabır, adalet, paylaşım, dürüstlük, sadakat, çalışkanlık, konukseverlik, duyarlılık ve fedakârlık kavramları ile sınırlandırılmıştır. Ortaya konan din ve değer ifadeleri, metin içerisinde betimlenerek din ve değerler çerçevesi şeklinde tablo halinde de gösterilmiştir.

\section{6. İlgili Literatür}

Türkiye'de sinema ve din-değer eğitimi üzerine yapılmış araştırmalardan söz etmek mümkündür. Yapılan araştırmaların bazılarına yer vermekle, bu çalışmanın alandaki ve literatürdeki yeri daha iyi anlaşılacaktır.

İnce (1991), 6-18 yaş aralığındaki bireylerin yaşamlarında çizgi filmin yeri ve önemini incelemiştir. Konuyla ilgili animasyon (çizgi film) sanatı, animasyonun tanımı, oluşumu, konusu, planlaması, çekim yöntemi, teknikleri ile animasyonun tarihi gelişimi ve animasyon sanatının eğitimdeki yeri hakkında bilgi vermiş, sonrasında anket yoluyla 6-18 yaş grubundaki bireylerin hayatında animasyonun yeri ve önemi ile ilgili ulaşılan bulguları ortaya koymuştur.

Yaren (2002), İran sinemasının doğuşu, dünü ve bugünü, devrim sonrasında İran sinemacılarının devletle ilişkisi, rejimin sinemaya bakışı ve uygulamalarını ele almıştır. Çalışmasında, İran'ın yakın dönemdeki siyasi ve toplumsal değişim ve dönüşümlerini temsil etme özelliği olduğu düşünülen Muhsin Mahmelbaf filmlerini incelemiştir.

Lüleci (2007), sinema ve din bağlamında Türk sinemasını incelediği çalışmasında, dokümanter yöntemi kullanarak görsel sanatlar ve din, Türkiye'de sinema ve din, dini/milli sinema akımı, 2000'li yıllarda sinema ve din konuları hakkında bilgi vermiştir. Bununla birlikte Türk sinemasında "din" kavramının nasıl kullanıldığını psiko-sosyal açıdan inceleyip, Türkiye'de sinema ile din anlayışının zamanla ne şekilde değişim gösterdiğini ortaya koymuştur.

Furat (2008), yaygın din eğitiminde televizyonun yeri ve önemini yetişkinler açısından ele aldığ çalışmasında, konuyu sır dizileri ve dini programlar ekseninde; sır dizilerinin ortaya çıkışı, içerikleri,

\footnotetext{
5 İran sineması ve Majid Madini'nin filmleri ile ilgili ayrıntılı bilgi için bkz. Nafisi, 1995; Yaren, 2002; Batur, 2005; Tapper, 2007; Nafisi, 2008; Yaghmoorala, 2013; Aktaş, 2015; Bozdağ \& Yavuz, 2019; Türkeri, 2019.
} 
genel özellikleri, işlenen konular, temalar, kullanılan anlatım metodları, üzerinde durulan kavramların izleyiciler tarafından nasıl algılandığı ve bu dizilerin din eğitimi açısından yorumlanması şeklinde ele almıştır. Bu kapsamda anket ve içerik analizi tekniklerinden yararlanmış, televizyon programlarının etkisini, bunlarla verilmek istenen mesajların dini kavramlarla nasıl transfer edildiğini ve alt mesajlarla da izleyiciye nelerin aktarıldığını ortaya koymuştur.

Yorulmaz (2010), sinema ve din eğitimi konusuna yer verdiği ve görsel-yazılı tarama modelini kullandığı çalışmasında, Hollywood, İran ve Türk sinemasını ele alarak, din eğitimi ve yaygın din eğitiminde sinemanın etkilerini, alt mesajlarını, bireysel ve toplumsal etkileri ile din eğitiminde kullanımını incelemiştir. Bununla birlikte bilhassa "değişmeyen dini mesajlar"ın transferi konusunda çağın bir ihtiyacı olarak sinemanın kullanılmasının öneminin ve sinema sektöründe etkisi olan bir din eğitimi aracı olabileceğinin altını çizmiştir. Bununla birlikte sinemayı bir eğitim aracı olarak ele almış ve animasyon, belgesel, tarihi, komedi, fantastik ve korku film türlerini din eğitimi açısından değerlendirmiştir. Ayrıca, sinemanın yaygın din eğitiminde (irşad filmleri, tebliğ filmleri, dindarları, dini değerleri küçük düşürme/kötü gösterme, dini çağrışımlı adları hedef alma, dini konularla ilgili yanlış bilgilendirme, sahne aralarında olumlu olmayan mesajlar, subliminal mesajlar, İslam'ı terörle ilişkilendirme ve yeni bir dinin oluşturulmaya çalışılması) ve örgün din eğitiminde (çalışma kağıtları, tartışma, empati kurma, karakter tahlili, görüntü tanımlama etkinliği, hikaye tamamlama, drama, film köşesi oluşturma ve film yapma ertkinlikleri vb.) kullanımını ortaya koymuştur.

Özgökbel Bilis (2011), araştırmasında, çizgi filmlerde değer kavramı üzerinden bir inceleme yapmıştır. Bu kapsamda, değer ve değerler konusu ile ilgili interdisipliner paradigmalar, değer çalışmalarına interdisipliner bir bakış, kitle iletişim çağında sosyal değişim/dönüşüm sürecinde değerlerin dönüşümü ve toplumsal değişimi ortaya koyan kuramsal paradigma konuları hakkında bilgi vermiştir. Bununla birlikte değerler açısından nitel çizgi film analizine değinerek, okul çağındaki çocukların izledikleri ile yetişkinlerin izlediği bazı çizgi filmleri ele almış ve çizgi filmlerde geçen değer aktarımı üzerinde durmuştur. Bu anlamda çizgi filmlerde çocuklara aktarılan değerleri ve olumsuz olduğunu düşündüğü davranışları ayrı ayrı ele alarak incelemiştir.

Yaghmoorala (2013), İranlı yönetmen Majid Majidi’ye ait filmleri sosyo-kültürel anlatı açısından incelediği çalışmasında, İran sinemasını tarihsel ve sosyal açıdan araştırmış, bu bağlamda İran sinema tarihini, sinema tarihi öncesi dönem, sinemanın başlaması, ilk yılları, yeniden doğuşu ve devrim sonrası gelişen İran sineması şeklinde sınıflandırmıştır. Sonrasında Majid Majidi sinemasına yer vermiştir. Ayrıca göstergebilimsel çözümleme yöntemi ile Majid Majidi'nin beş filminin (Cennetin Çocukları, Allah'ın Rengi, Yağmur, Söğüt, Kuşların Sesi) anlatı yapısını analiz ederek sinemasal ve ideolojik bir çözümleme yapmıştır.

Yağlı (2013), çocuğun eğitimi ve sosyal gelişimi üzerinde çizgi filmlerin rolünü ele almıştır. Konuyla ilgili örnek olarak ise Caillou ve Pepee çizgi filmlerini incelemiştir. Bu kapsamda çocukların sosyal gelişiminde televizyonun konumu, çizgi film-çocuk ilişkisi, çocukların dil kazanımı sürecinde çizgi filmlerin yeri, Caillou çizgi filminin nasıl doğduğu, Caillou hikâyelerinin çocuklar üzerindeki etkileri, Caillou'nun ailesi ve diğer karakterler, çocukların niçin Caillou'yu çok sevdiği, Pepee çizgi filminin nasıl doğduğu, Pepee'yi çocukların sevme nedeni, Pepee'nin yanında yer alan diğer karakterler ve bu filmde gizli bir tehlikenin olup olmadığı konularını mukayeseli olarak ele almıştır. Araştırmasında, çocukların izleyecekleri çizgi filmler belirlenirken, çocukların yaşı ve izleyecekleri çizgi filmlerin içeriğinin dikkate alınması gerektiği sonucuna ulaşmış ve konuyla ilgili önerilerde bulunmuştur.

Yorulmaz (2013a), Caillou çizgi filmini din-değer eğitimi açısından incelediği araştırmasında, Caillou çizgi filmi ile ilgili din-değer eğitimi ekseninde bir tespiti yapmayı ve filmin olumlu-olumsuz yönlerini ortaya koymayı hedeflemiştir. Hristiyanlık diniyle ilgili içerikler, farklı kültürlere ait figürler, değerlerle ilgili öğeler, şiddet-cinsellik unsurları, filmin kahramanının karakteristik özellikleri, zararlı bilinçaltı mesajlar ve Caillou'nun aile içi ilişkileriyle ilgili araştırma sorularına cevap bulmaya 
çalışmıştır. Bu çerçevede, kuram oluşturma ve doküman incelemesi yöntemlerini kullanmış ve araştırmanın verilerini; yayınlanan 309 bölümden sistematik örnekleme yöntemi ile seçtiği 40 bölümün içerik analizini yaparak elde etmiştir. Veri analizi sonucu, Hristiyanlık dini (dini ifade / pratik / sembol), farklı kültürler (batı medeniyeti / diğer kültürler), değerler (adalet, sorumluluk, paylaşma, özgüven vb.), şiddet (fiziksel / sözel / psikolojik), cinsellik (cinselliğe vurgu yapan kıyafet görüntüleri / arkadaşlık ilişkilerinde cinsel çağrışımlar / fiziksel cinselliğe ait unsurlar), Caillou'nun karakter özellikleri (uyumlu / paylaşımcı / yardımsever / affedici / korkak / huysuz bencil), alt metin / bilinçaltı mesajlar ve Caillou'nun aile yapısına ait bulguları ortaya koymuştur.

Yorulmaz (2013b), din ve değerler eğitimi perspektifinden Pepee çizgi filmini incelemiştir. Bu çalışmada, Pepee çizgi filmi ile ilgili din-değer eğitimi bağlamında bir durum tespiti yapmayı ve çizgi filmin olumlu-olumsuz özelliklerini ortaya koymayı amaçlamış, İslam diniyle ilgili yer alan unsurlar, bâtıl inançla ilgili iletiler, farklı kültürlere ait içerikler, şiddet ve cinsellik unsurları, Pepee'nin karakter özellikleri ile ilgili araştırma sorularına yanıtlar aramıştır. Araştırma kapsamında TRT çocuk kanalında yayına başlayan Pepee çizgi filmi toplamda yaklaşık 100 bölüm yayınlanmıştır. Bunların içerisinden seçtiği 40 bölümü (Benim annem güzel annem / Bir aşağıda bir yukarıda / Elimizdekilerin kıymetini bilmeliyiz / Evcilik mi golcülük mü? / Gerçek arkadaşlar birbirini üzmezler / Pepee zeybek öğreniyor / Pepee ve 6 Kurbağa / Hangisi kaç tane oyunu / Çöpler çöp kovasına atılır / Hophop / Pepee maymuşla tanışıyor / Pepee karate yapıyor / Müzik yapmak uyum ister / Hızlı yavaş hafif ağır / Önemli olan oyun oynamak / Pepee Trakya karşılaması öğreniyor / Pepee uçmak istiyor / Uyumazsak büyüyemeyiz / Uç uç uğur böceği vb.) incelemiştir. Sonrasında İslam dini, bâtıl inançlar, farklı kültürler, değerler, şiddet, cinsellik ve Pepenin karakter özellikleri ile ilgili bulgulara yer vermiştir.

Sarmış (2016), sinema ve din konusunu sekülerleşme bağlamında Hollywood Sineması örneği üzerinden ortaya koyduğu çalışmasında, sosyolojik açıdan Hollywood filmlerinin topluma yansıttıkları etkilere yer vererek, yeni bir sinema dilinin gelişmesi sürecini ele almıştır. Bu çerçevede, Holywood sinemasının post-modern hayatta tasarladığı din anlayışını ve seküler insanın/toplumun yaşam şeklini ortaya koymuş, dini açıdan film ("Shawshank Redemption", "Snowpiercer", "12 Angry Men", "Black", "38 Temoins”) çözümlemelerine yer vermiştir.

Koç (2016), değerler psikolojisi açısından Türk sinemasında din görevlisi imajını ele aldığı çalışmasında, Türk sinemasında rol model olarak gösterilen din görevlisinin sahnelerde yer alan kötü imajına yer vermiştir. Çalışmada doküman incelemesi yöntemi ve içerik analizi tekniğini kullanmıştır. Bu çalışmayı ortaya koyarken, Türk sinemasının psiko-sosyo-teolojik arka planının, belirlenen sinema örnekleri üzerinden semantik analizini yapmıştır.

Dural (2018), Aamir Khan'ın filmlerindeki dini öğeleri incelemiş, sinemanın doğuşu, Bollywood (Hindistan sineması) sinemasının gelişimi, sinemada dinin kullanımı, Aamir Khan'ın hayat1, filmleri, Hindistanın genel bilgileri (coğrafya, tarih, kültür) ve dinleri üzerinde durmuştur. Sonrasında Aamir Khan'ın filmlerinde yer alan dini öğeleri, mesajları ile birlikte ayrıntılı bir şekilde ortaya koymuştur.

Karaca (2019), değerler eğitimi bağlamında Rafadan Tayfa çizgi filmini ele aldığı çalışmasında, değer ve ahlak gelişimiyle ilgili kavramlar (adalet, doğruluk, hoşgörü, merhamet, tevazu, cömertlik, çalışkanlık, sabır, saygı, yardımseverlik, empati/diğergamlık, yurtseverlik/vatanseverlik, selamlaşma) üzerinde durarak, çocukluk dönemindeki ahlaki gelişime vurgu yapmıştır. Bununla birlikte değerlerin önemine işaret ederek, değerlerin ahlakla ilişkisini ortaya koymuş, sinemanın tarihsel gelişimi ile dünyada ve Türkiye'de çizgi filmin gelişim serüveni hakkında bilgi vermiştir. Sonrasında çocukluk dönemi değer eğitimine yer vererek, Rafadan Tayfa ile ilgili incelediği bölümleri, tablolar halinde göstermiş ve içeriğinde yer alan değerleri analiz etmiştir. Çalışmada litaratür taraması yöntemi ve betimsel analiz tekniğinden faydalanmıştır.

Türkeri (2019), teopolitik söylem ve sinema-gerçeklik inşası bağlamında Majid Majidi’nin "Hz. Muhammed: Allah'ın Elçisi” adlı filmini ele aldığı çalışmasında, İran sinemasındaki teo-politik etkinin sinema vasıtasıyla gündelik gerçeklik inşasındaki fonksiyonunu incelemiştir. Yöntem olarak söylem 
analizini kullandığı çalışmasının teorik çerçevesinde; söylem analizine, kuramsal temellere (yapısalcılık, post-yapısalcilık, post-modernizm, hermeneutik), fenemonoloji, sinema ve İran sinemasına yer vererek, konu ile ilgili örneklem çözümlemesini (Majidi'nin “Elçi”si, Ebû Tâlib'in Gözü, Görünmez Koruyucu Ali, Ehl-i Beyt'ten İmamate, Eşdeğer Tecrit Portreleri, Tez ve Antitez Karakterlerinin Mezhepsel Söylemi, Kurtarıcı İmajı ve 21. yy. Savaşları, Hz. Peygamber'in Mucizeleri, Ayetlerin Mesajlarına Karşılık Ayetlerin Söylemsel Mesajları) ayrıntılı bir şekilde ortaya koymuştur.

Bozdağ (2019), Majid Majidi'nin filmlerinde, çocukların ne şekilde yansıtıldığını ve karakteristik özelliklerini sosyo-kültürel bağlamda ele almıştır. Çalışmada yöntem olarak doküman analizinden yararlanmıştır. $\mathrm{Bu}$ çerçevede, sinemanın doğuşu, sinema oyunculuğunun gelişimi, sinemada çocuk oyuncu, İran sineması ve çocuk karakterler, İran tarihi, İran sineması ve İran sinemasında çocuk konularına değinmiş, Majid Majidi'nin örnek filmleri (Kaçakçı, Baba, Cennetin Çocukları, Cennetin Rengi, Yağmur, Serçelerin Şarkısı) üzerinden çocuk karakterlerini (aile, eğitim, ahlak, inanç vb. yönlerden) incelemiş ve analiz etmiştir.

Bozdağ \& Yavuz (2019), İran sinemasında çocuk karakterlere büyük önem veren Majid Majidi'nin "Cennetin Rengi" adlı filmindeki çocuk karakterleri sosyo-kültürel bağlamda ele aldığı araştırmasında, İran sineması (devrim öncesi ve devrim sonrası), İran sinemasında sosyal-kültürel kalıplar, Majid Majidi'nin hayatı, kariyeri ve İran sinemasında çocuğun yeri ve önemine vurgu yaparak, Majidi'nin sinemada kullanığı dil hakkında bilgi vermiştir. Daha sonra "Cennetin Rengi" filminde ön plana çıkan çocuk karakterleri sosyokültürel açıdan (davranış özellikleri / psikolojik özellikleri) analiz etmiş ve ayrı ayrı değerlendirmiştir.

Yukarıdaki yapılan çalışmalara bakıldığında, sinema ve din ilişkisi, sinema ve din-değer eğitimi, çizgi filmler/filmler ve din-değer eğitimi ve sinema alanının sektör haline geldiği ülkelerde çekilen filmlerin yansımalarına değinildiği anlaşılmaktadır. Ancak, bu çalışmalar sınırlı olmakla birlikte dindeğer eğitimi üzerine yaptı̆̆ filmleri ile dikkat çeken, uluslararası düzlemde ve İran sinemasında da öne çıan Majid'i'nin filmleriyle ilgili spesifik olarak din-değer eğitimi üzerine Türkiye'de yapılmış bir çalışmaya ${ }^{6}$ ulaşılamadığı görülmektedir.

Literatürde oluşan bu boşluktan hareketle çalışmada, İran sinemasının ön planda olan isimlerinden Majidi'nin yönetmenliğini ve senaristliğini yaptığı, genelde dünyada, özelde ise İslam dünyasında etkili olan "Hz. Muhammed: Allah'ın Elçisi” filmi üzerinden inceleme yapılmıştır. İnceleme, din-değer eğitiminde ön plana çıkan kavramlar üzerinden Majidi'nin sinema izleyicisine yansıtmak istediği mesajları ortaya koymak için “Hz. Muhammed: Allah'ın Elçisi” filmi izlenilmiş, film üzerinden verilmek istenen mesajlar ifade edilmeye çalışılmıştır. Seçilen filmde genel anlamda filmin konusu, işlenmek istenilen ve filmle ortaya konulan kavramlar açıklanmıştır.

Diğer çalışmalardan farklı olarak, İran sineması, yüzeysel bir bakış açısından ziyade, yönetmen Majid Majidi'nin kullandığı din ve değer temaları; ibadet, inanç, Kur'an ayetleri, dini karakterler, dini mekânlar, dini isimler, dini kıyafetler, değer ifadeleri, değer ifade eden davranışlar, kader, selamlaşma, cömertlik, hoşgörü, doğruluk, diğergamlık/îsâr, tevazu, iyilik, sevgi, şefkat, merhamet, nezaket, sorumluluk, emanet, sabır, adalet, paylaşım, dürüstlük, sadakat, çalışkanlık, konukseverlik, duyarlılık ve fedakârlık kavramları 1şı̆̆ında değerlendirmelere tabi tutulmuştur. Özellikle günümüzde din-değer eğitimi açısından genelde İran sineması özelde ise Majidi’nin filmleri hakkında yapılan sınırlı çalışmadan dolayı, bu araştırmanın alana ve literatürde oluşan boşluğun doldurulmasına katkı sağlaması beklenmektedir.

\footnotetext{
${ }^{6}$ Makaleler için bkz. İSAM, 2020; Lisanüstü tezler için bkz. YÖK, 2020.
} 


\section{Majid Majidi'nin Hayat, Filmleri ve "Hz. Muhammed: Allah'ın Elçisi” Filminin Din ve Değerler Eğitimi Açısından İncelenmesi}

\subsection{Majid Majidi'nin Kısaca Hayatı ve Filmleri}

Majid Majidi, 1959'da Tahran'da doğmuştur. Dramatik Sanatlar Akademisi'ndeki öğrenimini bitirmeden önce amatör yapımlarda rol almaya başlayan Majidi, 1980'li yıllarda kendine ait kısa filmler ve belgeseller yapmaya başlamıştır. 1992'de ilk uzun metrajlı filmini yöneten Majidi, ülkenin en çok bilinen yönetmenlerinden biri haline gelmiştir. "Cennetin Çocukları" filmi 1997 yılında "Akademi Ödülleri"nde aday gösterilmiştir. Onun övgüyle karşılanan diğer filmleri arasında San Sebastian Jüri Ödülü sahibi "The Father (1996)" ve Montreal Dünya Büyük Ödülü sahibi "Cennetin Rengi" ve "Baran" da yer almaktadır (Majidi, 2005; IMDB, t.y.e). 2015 yılında hem yönetmenliğini hem de senaristliğini yaptığı ve İran'ın bugüne kadar en yüksek bütçeli filmi (https://www.bbc.com/turkce/haberler-turkiye-37822507, 2020) olarak gösterilen "Hz. Muhammed: Allah'ın Elçisi" adlı filmi de ön plana çıkan filmlerindendir.

\section{Majid Majidi'nin Filmleri}

Majid Majidi’nin filmleri, eser sahibi olarak üzerinden yapılan filmi (Bollywood sinema sektörüne verdiği film senaryosu), yönettiği, yapımcıllı̆ııı üstlendiği ve senaristliğini yaptığı filmler (IMDB, t.y.c) olmak üzere dört başlıkta ele alınabilir.

Tablo 1: Eser Sahibi Olduğu Filmler (IMDB, t.y.c)

\begin{tabular}{lc}
\hline Film Adı & Yapım Yılı \\
\hline Bumm Bumm Bole & 2010 \\
\hline
\end{tabular}

Tablo 2: Majid Majidi'nin Yönettiği Filmler (IMDB, t.y.b)

\begin{tabular}{lc}
\hline Film Adı & Yapım Yılı \\
\hline Enfejar & 1981 \\
Hoodaj & 1984 \\
Baduk & 1992 \\
Akhareen Abadeh & 1993 \\
Khoda Miad & 1995 \\
Bacheha-Ye aseman & 1997 \\
Ruz-e Emtehan & 1998 \\
Rang-e khoda & 1999 \\
Baran & 2001 \\
Barefoot to Herat & 2002 \\
Olympics in Camp & 2003 \\
Beed-e majnoon & 2005 \\
Avaze gonjeshk-ha & 2008 \\
Mohammad Rasoolollah) & 2015 \\
(Hz.Muhammed: Allah'ın Elçisi) & \\
Beyond the Clouds & 2017 \\
The Sun & 2020 \\
\hline
\end{tabular}

Tablo 3: Yapımcılı̆̆ını Üstlendiği Filmler (IMDB, t.y.b)

\begin{tabular}{lc}
\hline Film Adı & Yapım Yılı \\
\hline Rang-e khoda & 1999 \\
Baran & 2001 \\
Barefoot to Herat & 2002 \\
Olympics in Camp & 2003 \\
Beed-e majnoon & 2005 \\
The Song of Sparrows & 2008 \\
\hline
\end{tabular}


Tablo 4: Senaristliğini Yaptığı Filmler (IMDB, t.y.d)

\begin{tabular}{lc}
\hline Film Adı & Yapım Yılı \\
\hline Ruz-e Emtehan & 1988 \\
Baduk & 1992 \\
Akhareen Abadeh & 1993 \\
Khoda Miad & 1995 \\
Bacheha-Ye aseman & 1997 \\
Rang-e khoda & 1999 \\
Gaz-e Mohajer & 1999 \\
Baran & 2001 \\
Barefoot to Herat & 2002 \\
Olympics in Camp & 2003 \\
Beed-e majnoon & 2005 \\
Avaze gonjeshk-ha & 2008 \\
Mohammad Rasoolollah) & 2015 \\
(Hz.Muhammed: Allah'ın Elçisi) & \\
Beyond the Clouds & 2017 \\
The Sun & 2020 \\
\hline
\end{tabular}

7.2. “Hz. Muhammed: Allah'ın Elçisi” Filminin Din-Değerler Eğitimi Açısından İncelenmesi

7.2.1.“Hz. Muhammed: Allah'ın Elçisi” Filminin Künyesi (IMDB, 2015a)

Filmin Orijinal Adı: Mohammad Rasoolollah

Filmin Yapım Yılı: 2015

Yönetmen: Majid Majidi

Senaryo: Hamid Amjad, Majid Majidi, Kambuzia Partovi.

Oyuncular: Sareh Bayat, Mina Sadati, Mahdi Pakdel, Ali Reza Shoja-Nouri, Mohsen Tanabandeh, Dariush Farhang, Siamak Adib, Ra'na Azadivar, Sadegh Hatefi, Pantea Mehdi Nia, Cafer Kasimi, Hamid Rıza Taç Devlet

Çekim Yeri: İran

Tür: Biyografik, Aksiyon, Dram

Süre: $178 \mathrm{dk}$.

Bütçe: 40 milyon Dolar ${ }^{7}$

\subsection{2. “Hz. Muhammed: Allah'ın Elçisi” Filminin Konusu ve İncelenmesi}

Bu film, Hz. Muhammed'le alakalı çekilen 2. film özelliği taşıması noktasında büyük bir öneme sahiptir. Dünyada Hz. İsa ve Hz. Musa hakkında birçok film çekilmiştir

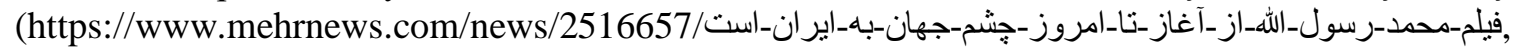
2019). Görüldüğü üzere dünya tarihine damga vurmuş, insanlığ 1 iyiliğe, güzel olana yönlendiren peygamberlerin yaşadıkları dönemleri film sahnelerine taşıyarak yaşamış oldukları dönemler gözler önüne serilmeye gayret edilmiştir.

7 Filmle ilgili ayrıntılı bilgi için bkz. https://www.bbc.com/turkce/haberler-turkiye-37822507, 2020; https://www.sabah.com.tr/fotohaber/magazin/hz-muhammed-allahin-elcisi-filmine-gisede-buyuk-ilgi/27, $\quad 2020 ;$ https://tr.wikipedia.org/wiki/Muhammed:_Allah\%27\%C4\%B1n_El\%C3\%A7isi, 2020. 
Film, 7. yy Mekke'de, İslam peygamberi Hz. Muhammed'in doğumundan önceki olaylarla başlayıp, çocukluk dönemini konu edinmektedir. Hz. Muhammed'in hayatını ele alan filmin, yönetmen Majidi'nin ifadesiyle üç bölümden/filmden oluşacağı, ilk filmde (yukarıda bahsedilen) Hz. Muhammed'in doğmadan önceki dönemde yaşananlar ve onun 12 yaşına kadar olan çocukluk dönemi yer almaktadır. İkinci filmin Hz. Muhammed'in çocukluk döneminden itibaren peygamberlik görevi verilinceye kadar olacağı, üçüncü filmin ise Hz. Muhammed'in peygamberlik göreviyle birlikte vefatına kadar olan kısmı konu edineceği belirtilmektedir (https://www.mehrnews.com/news/2516657/فيلم-محمد-رسول_الله_از_آغاز-تا_امروز-جشم-جهان_به_ايران_است, 2019).

Majid Majidi, filmi hakkında verdiği röportajlarında özellikle şu ifadeleri vurgulamaktadır:

"Ne Batı kaynaklarında, ne de diğer ülkelere ait arşivlerde çok güvenilir bilgilere ulaşmak zor. Benim bu filmle yapmaya çalıştığım gerçekçi bakış açısıyla İslam'ı anlatmak. Özellikle Batılılara doğru simgeleri seçerek doğru haliyle İslam'ı aktarmak istiyorum. Batılıların İslam'ı yanlış bildiklerini ve İslam'ın onlara yanlış aktarıldığını düşünüyorum. Son yıllarda özellikle İslam'ı sadece Taliban ile özdeşleştiren yanlış bir yargı hâkim. Tüm dünyaya bunun yanlış olduğunu, bu filmle söylemek ve doğrusunu göstermek istiyorum. $\mathrm{Bu}$ film, sadece müslüman ülkelerde değil, tüm dünya genelinde gösterime girecek. $\mathrm{Bu}$ nedenle doğru dili seçmeliyiz. Hz. Muhammed'in çocukluğu ile başlayacak olan hikâye, peygamber olarak seçilmesini de işleyecek. Bunun doğru tanıtım olacağını düşünüyorum; çünkü bu zamanı en ince detayına kadar işleyeceğiz.” (Genç, t.y.).

Majid Majidi filme “Allah'ın adıyla” başlamaktadır. Müslümanlara yapılan boykot yılıyla devam eden sahneler, Ebû Süfyân, Kureyş'in önde gelen kabilelerinin liderlerini toplayarak, "Hz. Muhammed'in Kureyş'e getirdiği bizim düzenimizi bozacak, kölelerle aynı sofradan yemek yemeye, kadınlarınızı başınızın üstünde tutmaya hazır mısınız?" ifadesiyle kabile reislerinde $\mathrm{Hz}$. Muhammed'e karşı ön yargı oluşturmaktadır [08:11]. Ebû Süfyân, Ebû Tâlib'le yan yana yürürken ona "Muhammed'in davetinden bende etkilendim." demekte ve bunu diğerlerine söylememesinin nedenini şöyle ifade etmektedir: "Eğer ben Ebû Süfyân olarak Muhammed'in dinini seçeceksem, Muhammed'in bana ne vereceğini bilmem gerekir." Bu sahnede Ebû Tâlib'in ona karşı ifadesi "İman alınıp satılmaz Ebû Süfyân" diyerek inancın bir çıkar uğruna harcanamayacağı ifade edilmektedir [10:59].

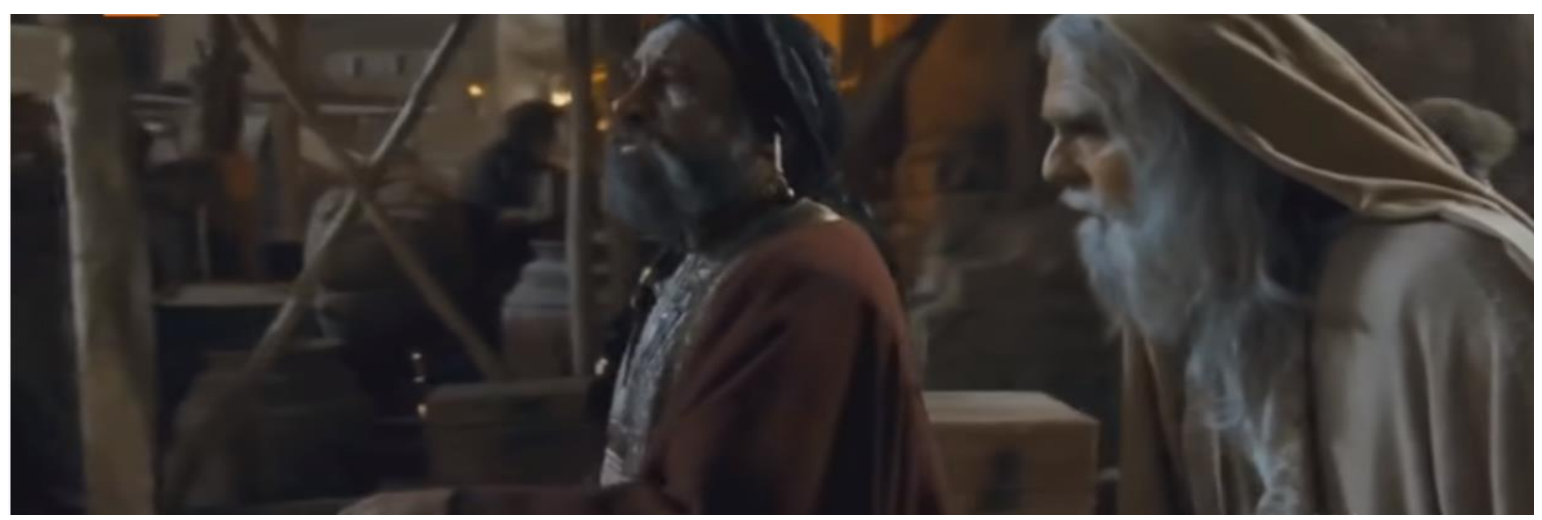

Resim 1: Ebû Süfyân'ın, Ebû Tâlibe Hz. Muhammed'in Davetinden Etkilendiğini Söylediği Sahne Bkz. IMDB, 2015b, [10:59].

Kur'an-1 Kerim'de “... O halde insanlardan korkmayın, benden korkun, ayetlerimi hiçbir değerle değiştirmeyin; Allah'ın indirdiği ile hükmetmeyenler, işte onlar kâfirdirler." (Mâide, 5/44) ifadesi kullanılmaktadır. Bu sahnede İslam inancının bir bedel karşıllğı satılamayacağı, Kur'an-1 Kerim'den alınan ayet çerçevesinde işlendiği açık bir şekilde görülmektedir. Majidi yukarıda 
belirtilen röportajında, filmleri hakkında ve özellikle "Hz. Muhammed: Allah'ın Elçisi” filminde Kur'an ayetlerinin temel senaryoyu oluşturduğunu ifade etmektedir (Genç, t.y.).

Ebû Süfyân, Haşimoğulları'nın Hz. Muhammed'i korumasından vazgeçmesini talep etmektedir. Ebû Tâlib bu istek karşısında, yetim ve öksüze sahip çıkma adına amcalık göreviyle akrabalık bağlarını hatırlatarak, Ebû Süfyân'a böyle bir talebin kendisi hayattayken olamayacağını vurgulamıştır [12:20]. Burada ailede bağların kuvvetliliğinin ve öksüze, yetime sahip çıkılması gerektiğinin alt mesaj olarak verildiği söylenebilir.

Din ve değerler eğitimi açısından Ebû Süfyân'ın talebi ve Ebû Tâlib'in tutumu; emanete sahip çıkma, yetim ve öküzü koruma gibi değerlerin sahnede yansımasını göstermektedir. İslam medeniyetinde "emanet" değeri genel anlamda, "güvenilen bir kimseye koruması için geçici olarak tevdi edilen şey" (Râgıb el-İ́sfahânî, 1961; ayrıca bkz. Toksarı, 1995, ss. 81-83; Aktan, 1995, s. 83, 84) olarak ifade edilmektedir.

“Hz. Muhammed: Allah’ın Elçisi Filmi”, Hz. Muhammed'in peygamberlik süreci ve Ebû Süfyân'ın onun peygamberliğini kabul etmeyişi ile başlamaktadır. Filmin devamında geçmiş zamana dönülerek "fil hadisesi” anlatılmaktadır. Bu sahnede Ebû Tâlib gökyüzüne bakarak Fil Suresi’nin ayetlerini dinlemekte, gelen fil ordusunun halinin ne olacağı hakkında bilgi edinmektedir [14:33].

Habeşistan Devleti'nin Yemen Valisi Ebrehe, yanına kadar gelen Kâbe'nin anahtarının sahibi ve Kureyş'in lideri Abdülmuttalib'le görüş̧mektedir. Abdülmuttalib, Ebrehe'den sadece gasp edilen 100 devesinin bırakılmasını istemekte, Ebrehe bu istek karşısında şaşırmaktadır. Abdülmuttalib'e dönerek "şehrini kurtarmak için yalvarmayacak mısın?" deyince, Abdülmuttalib "Ben develerimin sahibiyim. Kâbe'nin sahibi var. O'nu O yüce sahibi korur!" cevabını vermektedir [23:32]. Bu sahnede tevekkülü ve teslimiyeti işleyen Majidi, dini değerler üzerinden insanların kendi yapabileceklerini yapmalarını, gerisini Allah'a bırakmaları gerektiğini vurgulamaktadır.

Majidi İslam kaynaklarında yer alan Ebrehe'nin ordusunun yok olmasına sebep olan kuşların (bkz. https://kuran.diyanet.gov.tr/tefsir/sure/105-fil-suresi, 2019) ağızlarından attıkları taşların, Ebrehe'nin ordusu üzerine alev taşları gibi düşmesi sahnesinde "mucize" kavramını işlemektedir [29:51]. Kâbe'ye karşı duyarlı olunması gerektiği, Allah'ın yeryüzünde bozgunculuk çıkaracaklara karşı neler yapabileceği bu sahnede en detaylı görsellerle işlenmektedir.

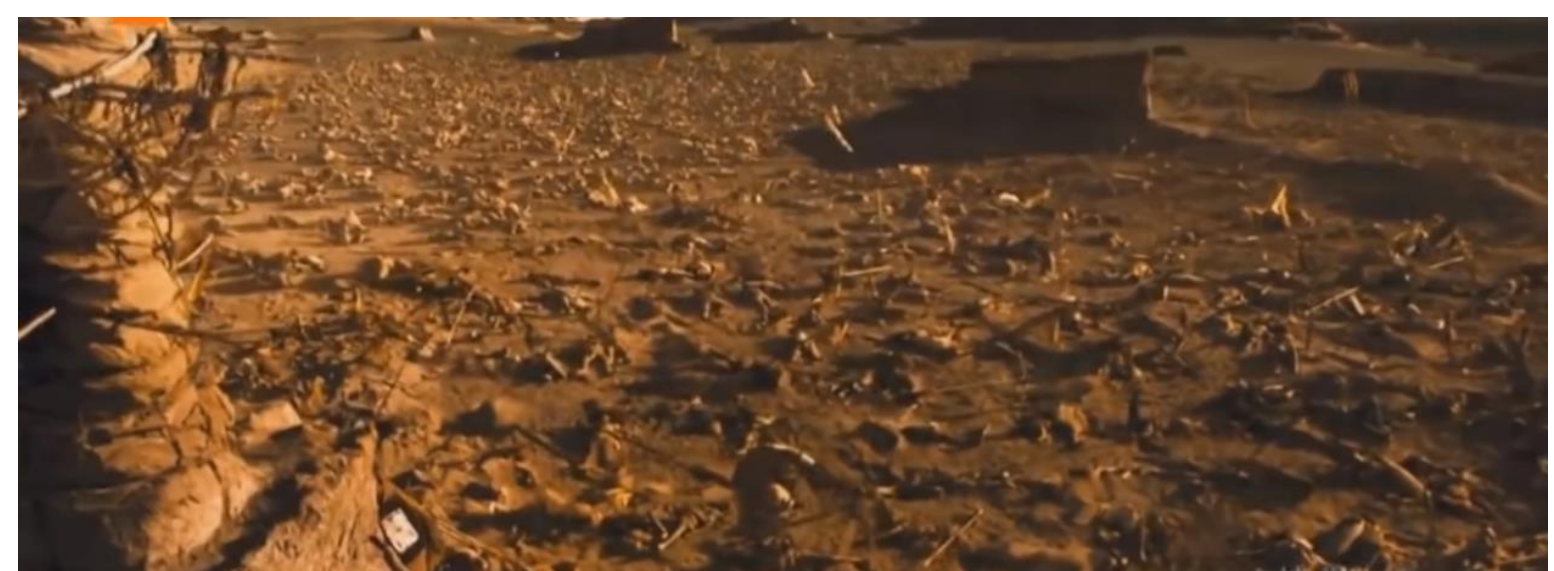

Resim 2: Ebrehe'in Ordusunun Kuşların Ağızlarından Attıkları Taşlarla Yok Olması Sahnesi

Bkz. IMDB, 2015b, [29:51].

Hz. Muhammed'in dünyaya gelişinin tasvir edildiği sahnelerde, Hz. Muhammed herkesin beklediği bir kurtuluş olarak görülen insan profili şeklinde işlenmiştir. Hz. Muhammed'in dünyaya gelişindeki bir takım olaylara sahnede yer verilmiştir. Bunlar putların yıkılması, kurak olan kuyuların suyla dolması gibi olaylarla tasvir edilmiştir. Özellikle putların yıkılışı, din ve değerler eğitimi 
açısından yansıtılmak istenen mesajın hak - bâtıl kavramlarıyla ortaya konulduğunu göstermektedir [34:42].

Hz. Muhammed'in dedesi olan Abdülmuttalib'in, Hz. Muhammed'in dünyaya gelmesi sebebiyle Mekke'de bulunan tüm insanları yemeğe davet etme sahnesinde, özellikle aç olan insanları sofrasına çağırması, kendi elleriyle ikramlarda bulunması ile paylaşmanın zengin veya fakir gözetmeksizin herkese yapılması gerektiği vurgulanmıştır. Aynı zamanda tevazu ve konukseverliğin önemine de dikkat çekilmiştir [36:18].

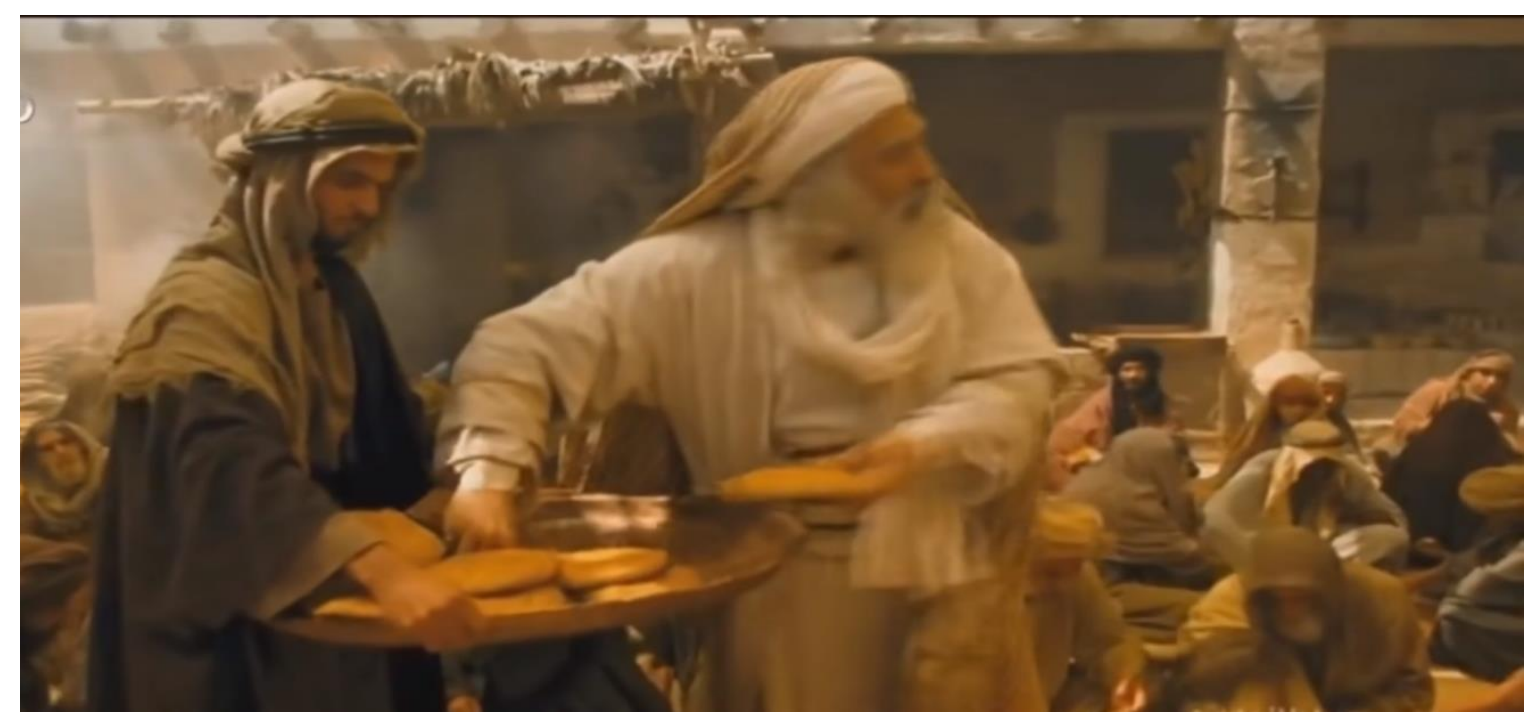

Resim 3: Abdülmuttalib'in Torunu İçin Verdiği Yemekte Kendisinin Yemek Dağıtması Sahnesi Bkz. IMDB, 2015b, [36:01].

Mekke toplumunda doğan çocuklara kendi kabilesinin putlarının isimleri verilirken, Abdülmuttalib torunun ismini 'Muhammed' koymuştur. Anlamını da "övülen ve övgüye layık olan kişi”" şeklinde açıklamıştır [46:18].

Hz. Muhammed'in dünyaya gelişinden sonra annesi Amine'nin sütünün azlığı sebebiyle, amcası Ebû Leheb'in cariyesi Süveybe'nin Hz. Muhammed'e süt vermesi, fakat Ebû Leheb'in eși Ümmü Cemil'in isteği üzerine cariyenin süt vermeyi kesmesinden sonra Abdülmuttalib oğluna şu ifadeleri kullanmaktadır: "Cariyenin emzirdiği sütün parasını öderiz. İstersen cariyeyi satın alırız." Bunun üzerine oğlu Ebû Leheb "Cariye eșime hediyemdir. Kullanma hakkı ona aittir." dedi. Bunun üzerine Abdülmuttalib "Kardeşinin oğlunun anne sütüne ihtiyacı varken bu kin ve öfke niye? Kabil bile kendi kardeşine kin ve nefret beslemiyordu, Ebû Leheb" der. Bu sahnede Ebû Leheb ve eşi Ümmü Cemil'in kıskançlıkları ve kıskançlıklarından dolayı kendi öz kardeşi olan Abdullah'ın oğlu Hz. Muhammed'in aç kalmasını, hatta ölmesini bile önemsemedikleri gösterilmektedir. Burada "kıskançlık" duygusunun insanda ne gibi bir tahribata yol açtı̆̆ açık bir şekilde sergilenmektedir [51:47].

Hz. Muhammed'in doğumundan sonra yaşanan mucizeler, Yahudilerin beklediği kişiyi göstermektedir. Filmin bir sahnesinde Yahudi âlimler bir araya gelerek o gece olan olayların asırlardır beklenen kurtarıcının müjdesi olduğunu konuşurlar. Bunun üzerine Yahudi âlimler heyeti, yıldızların parladığı ve gecenin aydınlandığı o gece, doğan Yahudi erkek çocuklarının tespit edilmesini ister. Fakat ne kadar arasalar da o gece Yahudiler içinde bir erkek çocuk dünyaya gelmemiştir. Bunun üzerine Yahudi heyetinin seçtiği kişi, Yahudilerin içinde bir kurtarıcının gelmediğini, yaşanan doğa olaylarının Mekke'yi ișaret ettiğini söyler. Bunun üzerine bir hahamla görüșen kiși hahama, "gelecek kurtarıcı bizim kavmimizden olmazsa" diye sorar. Haham, "nas1l olur da bir hak peygamberin bizim kavmimizden gelmeyeceğini düşünebilirsin!” diye cevap verir. Bu sahnede Yahudilerin kendilerini 
üstün bir ırk olarak gördüğü aktarılmakta ve bu aktarım da tereddütsüz bir inançla ifade edilmektedir $[54: 30]$.

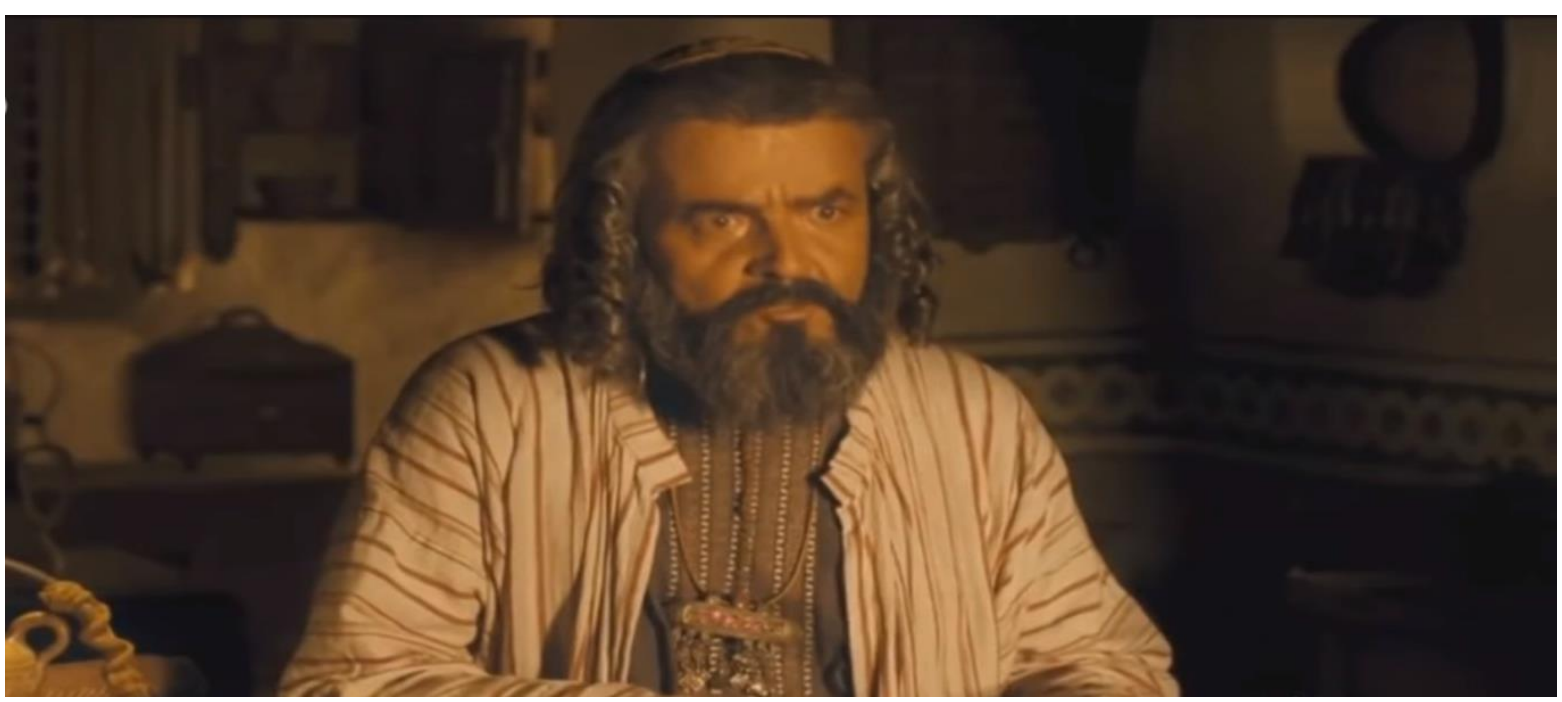

Resim 4: Yahudi Heyetinin Görevlendirdiği Kişi ile Bir Hahamın Diyalogu Sahnesi Bkz. IMDB, 2015b, [53:52].

Hz. Muhammed'in sütannesi olacak olan Halime, bir eşi, bir kızı olan yoksul bir aileye sahiptir. Mekke'ye sütannelik yapmak için ailesiyle gelir. Mekke içinde dolaşırken sütanne arayan bir kadını görür. Arkasından giderken başka bir sütanne adayı, durumum çok kötü diye gitmeyi istediği kadının arkasına onun da düştügünü görünce, o kadının arkasından gitmeyi istemez. Halime bu davranışıyla kendinin, eşinin ve çocuğunun durumu sıkıntılı olmasına rağmen fedakârlık etmektedir. Sütanne arayan kadının o sütannenin ihtiyacı olduğunu söylediğini işitince rızkını o kadına bırakmaktadır. Çok kısa, ara bir perdede kalan bu sahnede, kendinden önce başkasını düşünmekle ilgili diğergamlık ve îsâr ${ }^{8}$ kavramlarının alt mesajları işlenmektedir.

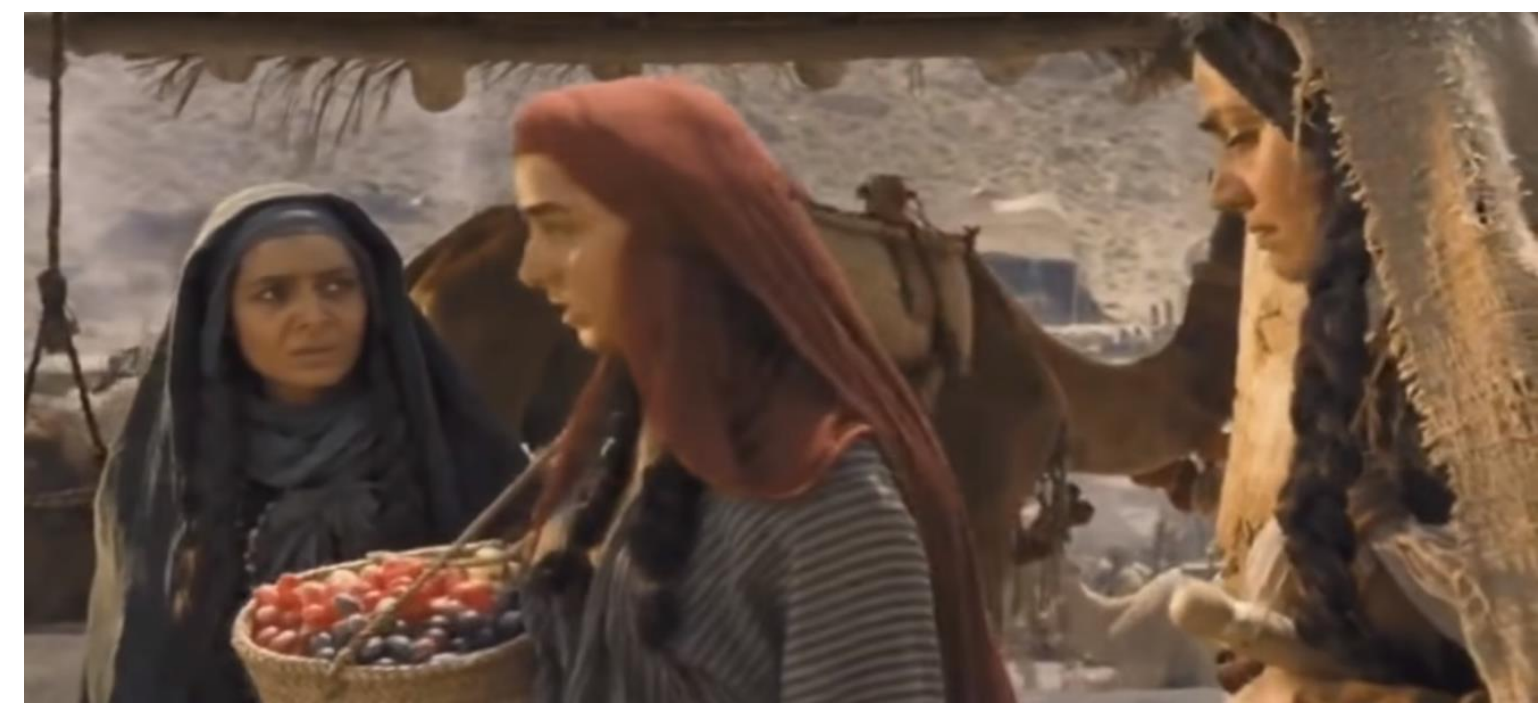

${ }^{8}$ İsâr ve diğerkâmlık kavramları ile ilgili bilgi için bkz. Çağrıcı, 2000, ss. 490, 491.

Turkish Studies - Education, 15(4) 
Resim 5: Halime’nin Fedakârlık Yaptığı Sahne, Bkz. IMDB, 2015b, [56:59].

Hz. Muhammed'in sütannesi olacak olan Halime, gerektiğinde kendisi ve ailesinden daha çok diğer insanları düşünen biri olarak anlatılmaktadır [57:27].

Halime'nin, Hz. Muhammed'i kucağına alır almaz gözyaşları içinde kalması, şefkat, merhamet gibi duygularının anne sıcaklığında işlendiğini göstermektedir. Aynı sahnede bir tarafında sütü kesik olan Halime'nin Hz. Muhammed'i kucağına alır almaz sütü gelmesiyle Hz. Muhammed ile ilgili mucizeye yer verilmiştir [01:04:51].

Amine, "Bölge halkı, Hz. İbrahim'in dini ve Allah inancından gitmek yerine, Kâbe içine ve etrafına taştan putlar yapıp onlara tapmayı tercih ettiler." diyerek halkın putperest bir toplum haline geldiğini vurgulamaktadır. Dini kavramlar açısından inancın ne hale geldiğinin vurgulandığı sahnede, özellikle Allah inancına bağlı olmaları gerekirken putlara tapmalarının yanlış olduğu sergilenmektedir [01:30:42].

Amine, Hz. Muhammed'i babası Abdullah'ın kabrinin olduğu Yesrib'e götürür. Hz. Muhammed babasının kabri başında toprağına elini sürerek dua eder. Bu sahnede mezar kültürünün kısmi olarak yansıtıldı̆̆ı söylenebilir [01:37:09].

Filmin dikkat çeken noktalarından birisi de Hz. Muhammed'in annesi Amine'nin ölümüdür. Tüm vücudunun ateşler içinde kalması, annesini ne kadar çok sevdiğini, ayrıllğın ne demek olduğunu küçük yaşta sezmesinin anlatıldığı sahne "anne sevgisi ve önemini” vurgulamaktadır [01:46:26].

Abdülmuttalib, Hz. Muhammed'e hac zamanı geldiği, Kâbe'nin etrafinın temizlenmesi gerektiğini ve insanların Hz. İbrahim'in dinine putperestliği karıştırdığını anlatır. Hz. Muhammed'le birlikte Hacer'ul Esved'in yanına giderek dua ederler ve arkasından birlikte tavaf ederler. Bu sahne ile dini kavramlar verilerek, Hz. İbrahim döneminde de hac, tavaf ve dua ibadetinin yapıldığı ortaya konulmaktadır [01:54:38].

Hz. Muhammed'in dedesi belli bir süre sonra rahatsızlanır ve yatağa düşer. Hasta yatağında tüm akrabalarını toplayarak, Hz. Muhammed'i amcası Ebû Tâlib'e emanet eder. Abdülmuttalib, Ebû Tâlib'e Hz. Muhammed'i emanet ettiği sahnede şu ifadeleri kullanır. "Ebû Tâlib ona babalık yap, babası Abdullah'1 koklayamadı, anne şefkatini pek göremedi." Bu sözlerde Hz. Muhammed'in yaşadığı duygusal anlamda boşluktan bahsedilmekte, Ebû Tâlib'den Hz. Muhammed'i koruması, kendi evladı gibi görmesi ve ona hak ettiği sevgiyi göstermesi istenmektedir [02:01:12].

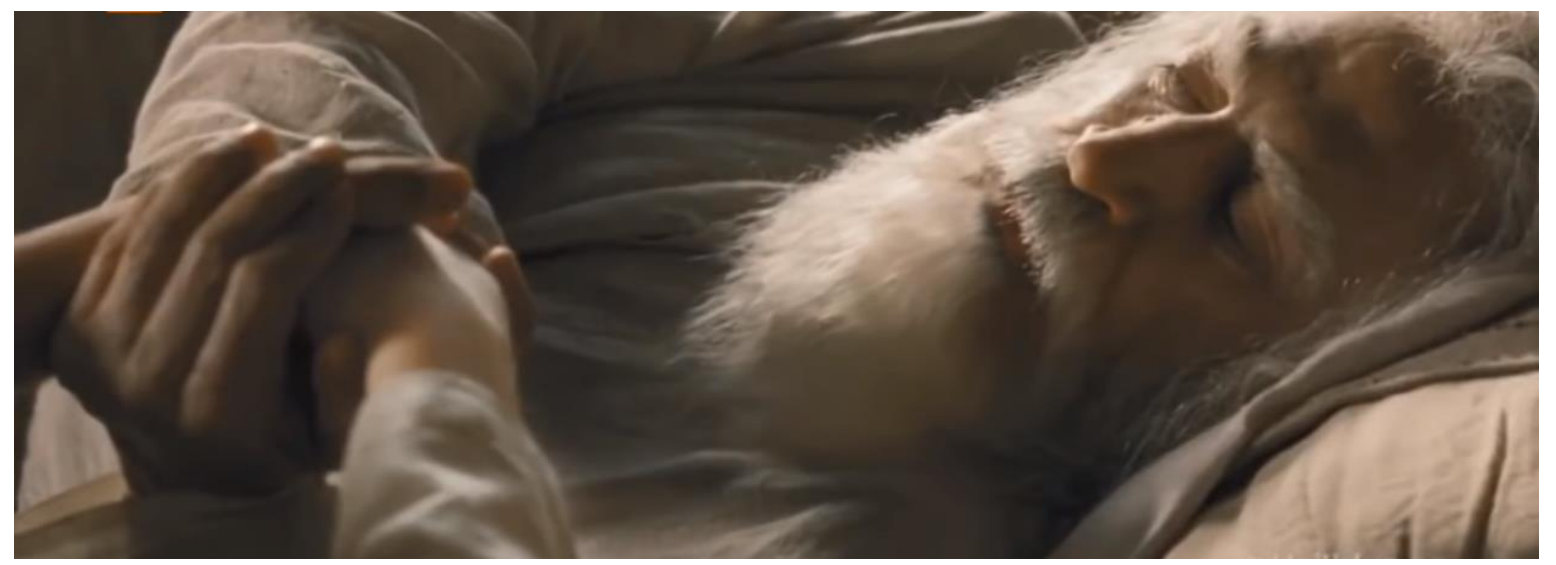

Resim 6: Abdülmuttalib, Hz. Muhammed'i Amcası Ebû Tâlib'e Emanet Ettiği Sahne Bkz. IMDB, 2015b, [02:01:03]. 
Hz. Muhammed'in bir gün koyun ve keçi süreleri güderken, karşılaştığı bir manzara anlatılmaktadır. Bir baba kız çocuğu doğurduğundan dolayı eşini dövmekte, ona hakaret ederek anneye; doğurduğu kızı öldüreceğini, bir boğaz daha taşıyamayacağı, neden erkek doğurmadığı ile ilgili bağırmalarına karşın Hz. Muhammed çocuğu kucağına alarak, babasına "tıpkı sana benziyor, kız çocuğu rahmettir" demektedir. Bu davranışı ile toplumda kız çocuklarına karşı tutum ve davranışı değiştirmek istemektedir. Adam bu sahnede k1z çocuğunu öldürmekten vazgeçer. Burada merhametle dokunulan her insanın doğruya yönelebileceği mesajının verildiği ifade edilebilir [02:09:24].

Ebû Tâlib ticaret kervanı oluşturarak yeğeni Hz. Muhammed'le ticaret yapmak için kuzeye yönelirler. Bir yerde konaklarlar. O yerde Bahira adında bir rahip gelen kervanda bir takım alametler fark eder. Kervan nereye giderse üzerlerindeki bir bulut tabakasının onları takip ettiğini görür. Rahip Bahira, kervana haber yollar ve akşam yemeğinde tüm kervandakilerle buluşmak istediğini söyler. Ebû Tâlib daveti kabul eder. Yemekler yenildikten sonra rahip Bahira Ebû Tâlib'e, kervanınızdaki genç delikanlının bir peygamber olduğunu, iki omuzu arasında bir mührün olduğunu anlatır. $\mathrm{Bu}$ mührün peygamberlik mührü olduğunu söyleyince Ebû Tâlib, rahip Bahira'nın söyledikleri ve uyarıları üzerine kervanını Mekke'ye geri döndürür. $\mathrm{Bu}$ sahnede rahibin $\mathrm{Hz}$. Muhammed'i müjdelemesi, dini bir figür olarak gösterilmiştir [02:19:53].

Deniz kenarında yaşayan bir topluluğa uğrayan Ebû Tâlib, Hz. Muhammed'in bir putun yanında kadın ve kız çocuklarının deniz dalgalarından boğulacak bir yerde durduklarını görerek yanlarına gider. Putperestlerin, kadınları ve kız çocuklarını putun etrafına bağladıkları ipleri çözerek onları kurtarır. Sonra bölge halkının açlıktan dolayı zor durumda olduğu ve bu yüzden kadın ve kızları denize armağan ettiği anlatılınca Hz. Muhammed'in mucizesi gerçekleşir. Deniz dalgaları bölge halkının yemesi için balıkları deniz kenarına getirir. Sahneye bakıldığında yine merhametsizlik, insanın yalnızca kendini düşünmesi, ayrımcılık yapma gibi duyguların işlendiği görülmektedir [02:32:14].

Film, Mâide suresi 8. ayetin okunmasıyla bitmektedir. "Ey iman edenler! Allah için hakk1 ayakta tutun, adaletle şahitlik eden kimseler olun. Herhangi bir topluluğa duyduğunuz kin, sizi adaletsiz davranmaya itmesin. Adaletli olun; bu, takvâya daha uygundur. Allah'tan korkun. Şüphesiz Allah yaptıklarınızdan haberdardır." (Mâide, 5/8, ayrıca bkz. https://kuran.diyanet.gov.tr/tefsir/M\%C3\%A2ide-suresi/677/8-ayet-tefsiri, 2019).

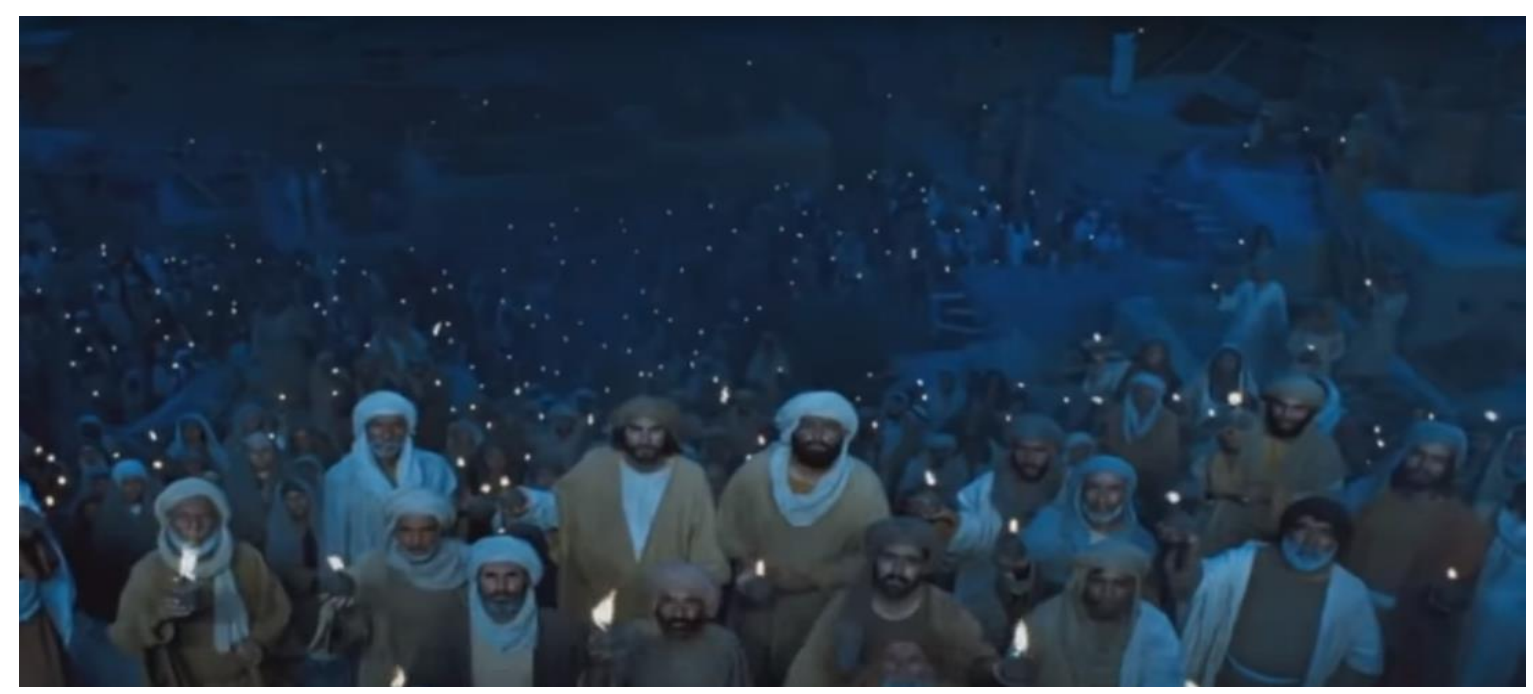

Resim 7: Mâide Suresi 8. Ayetin Okunması Sahnesi, Bkz. IMDB, 2015b, [02:38:47]. 
Son sahnede; hak, adalet, takva kavramlarının ve Allah'ın her şeyi hakkıyla bildiğinin vurgusu yapılmaktadır [02:40:45].

"Hz. Muhammed: Allah'ın Elçisi" filminde din ve değerler eğitimi açısından incelenen değerler, dini çerçeve ve değerler çerçevesi şeklinde aşağıdaki tabloda verilmiştir.

Tablo 5: “Hz. Muhammed: Allah’ın Elçisi” Filminde İncelenen Din ve Değerler Kavramları

\begin{tabular}{|c|c|c|c|c|c|c|c|c|c|c|c|c|c|c|c|c|c|c|c|c|c|c|}
\hline \multicolumn{23}{|c|}{ HZ. MUHAMMED: ALLAH'IN ELÇİSI FILMİ DIN VE DEĞERLER TABLOSU } \\
\hline 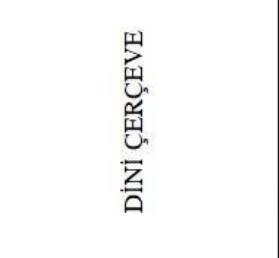 & 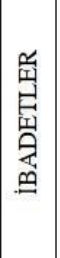 & 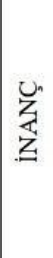 & 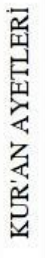 & 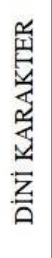 & 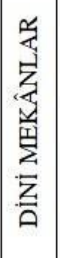 & 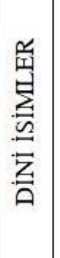 & 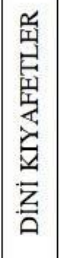 & 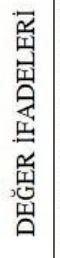 & 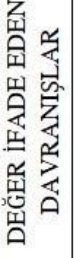 & 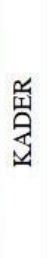 & & & & & & & & & & & & \\
\hline DEĞERLENDÍRILMESI & $\sqrt{ }$ & $\sqrt{ }$ & $\sqrt{ }$ & $\sqrt{ }$ & $\sqrt{ }$ & $\sqrt{ }$ & $\sqrt{ }$ & $\sqrt{ }$ & $\sqrt{ }$ & $\sqrt{ }$ & & & & & & & & & & & & \\
\hline 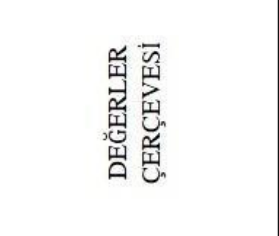 & 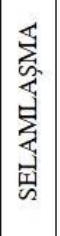 & 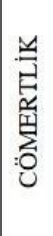 & 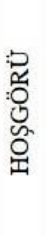 & 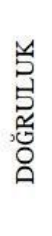 & 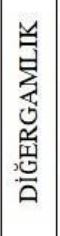 & $\begin{array}{l}\text { 离 } \\
\text { 㐬 }\end{array}$ & 兰 & 思 & 窎 & 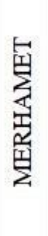 & $\begin{array}{l}\text { 氙 } \\
\text { 离 } \\
\text { 至 }\end{array}$ & 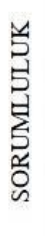 & 武 & $\begin{array}{l}\text { 学 } \\
\text { 出 }\end{array}$ & $\begin{array}{l}\text { 岛 } \\
\text { 夏 }\end{array}$ & 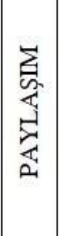 & 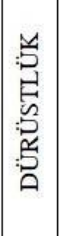 & 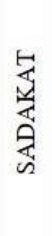 & 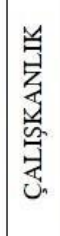 & 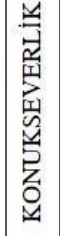 & 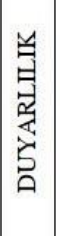 & 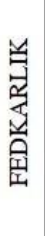 \\
\hline DEĞERLENDIRILMESi & $\sqrt{ }$ & $\sqrt{ }$ & $\sqrt{ }$ & $\sqrt{ }$ & $\sqrt{ }$ & $\sqrt{ }$ & $\sqrt{ }$ & $\sqrt{ }$ & $\sqrt{ }$ & $\sqrt{ }$ & $\sqrt{ }$ & $\sqrt{ }$ & $\sqrt{ }$ & $\sqrt{ }$ & $\sqrt{ }$ & $\sqrt{ }$ & $\sqrt{ }$ & $\sqrt{ }$ & $\sqrt{ }$ & $\sqrt{ }$ & $\sqrt{ }$ & $\sqrt{ }$ \\
\hline
\end{tabular}




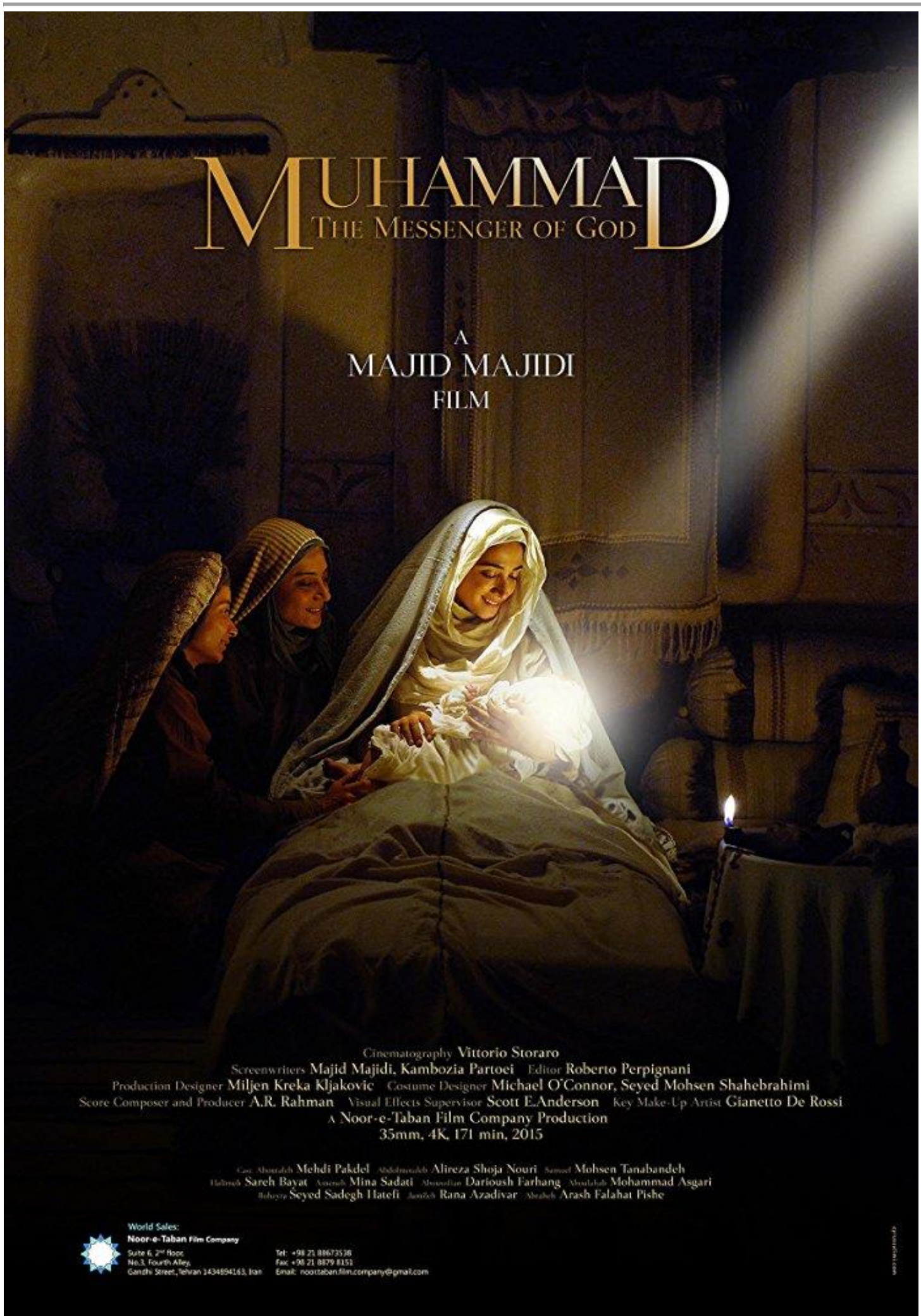

Resim 8: "Hz.Muhammed: Allah'ın Elçisi (Mohammad Rasoolollah)" Filminin Afişi (IMBD, 2015a). 


\section{Sonuç}

Sinema, ilk yıllarından bu yana bir eğlence aracı olmanın yanında; bir ifade aracı, gerçeğin aynası, sanat dalı, propaganda aygıtı gibi pratiklere de hizmet etmiştir. Tüm bu pratiklere hizmet ederken de bir olayı, bir insanı, bir derdi, bir bunalımı, bir aşkı, bir ayrılı̆̆ı veya bir gerçeği ele alarak konu edindiğini nesnesi haline getirmiştir. Bu süreçte zaman zaman bireylerin ve toplumun psikososyal gelişiminde önemli olan din-değer eğitimi merkezli olaylar da sinemanın nesnesi haline gelmektedir. Buna bağlı olarak informal merkezli din-değer aktarımında da son yıllarda ön plana çıkan sinema, filmlerde vermek istediği mesajlarla bireyleri ve toplumları etki altına almaktadır.

$\mathrm{Bu}$ kapsamda din ve değer eğitimi açısından incelenen Majidi'nin “Hz. Muhammed: Allah'ın Elçisi" adlı filminde din ve değer ögelerine yer verilerek, yardımlaşma, paylaşma, helalharam dengesi, dürüstlük, vicdan, kardeşlik, sabır gibi değerlerin; nefret, kıskançlık, bencillik vb. olumsuz duygu ve düşüncelerin nasıl önüne geçtiği gösterilmektedir.

Hz. Muhammed'in hayatının din-değer eğitimi açısından ayrıntılı olarak ele alındığı bu çalışma ile, sinema üzerinden verilen mesajlarla/alt mesajlarla dini çerçevede; ibadet, inanç, Kur'an ayetleri, dini karakterler, dini mekânlar, dini isimler, dini kıyafetler, değer ifadeleri, değer ifade eden davranışlar, kader, değerler çerçevesinde ise selamlaşma, cömertlik, hoşgörü, doğruluk, diğergamlık/îsâr, tevazu, iyilik, sevgi, şefkat, merhamet, nezaket, sorumluluk, emanet, sabır, adalet, paylaşım, dürüstlük, sadakat, çalışkanlık, konukseverlik, duyarlılık ve fedakârlık değerlerinin ortaya konularak, genelde İslam dininin, özelde Hz. Muhammed'in üzerinden din-değer kavramlarının önemine vurgu yapıldığı ve bu konuda farkındalık oluşturulduğu söylenebilir. Ayrıca evrensel değerlerle Hz. Muhammed'in rahmet ve merhamet yönünün ele alındığı ifade edilebilir.

Din ve değerler eğitimi açısından, "Hz. Muhammed: Allah'ın Elçisi” filminin oldukça zengin bir değer içeriğine sahip olduğu görülmektedir. Bu bağlamda insan, doğduğu andan itibaren gelişim evrelerine göre şekillenmeye devam eder. Din ve değerlerin işlendiği ilk ortam aile, sonra sosyal çevredir. İnsan hayatına girmesiyle birlikte, onun şekillenmesini önemli ölçüde etkileyen bir faktör de teknoloji olarak karşımıza çıkmaktadır. Kitle iletişim araçlarından sinema, kitlelere ulaşma anlamında diğer iletişim araçlarını gölgede bırakmaktadır. Dolayısıyla insanın iyiye, doğruya ve güzele doğru yönelmesi ve şekillenmesinin, din ve değerlerin toplum içinde hızlı ve etkili bir şekilde yayılmasının, sinema üzerinden etkili bir şekilde olabileceği vurgulanmaktadır.

İslam dünyasında sinemanın yer bulması ve böyle çalışmaların ortaya çıkmasının, din ve değerlerin anlatılmasına önemli katkılar sağladığı söylenebilir. Bir görevi de tebliğ olan müslümanın, araçsal anlamda elini kuvvetlendiren sinema sektörünü kullanması, çağın gereksinimi olarak görülmelidir. Diğer yandan İslam dünyasında çekilen filmlerin, evrensel değerler üzerinde yansıttığı olumlu etkilerinin üzerinde durulmasının, toplumun informal din ve değer eğitimine katkı sağlaması bakımından önem arz ettiği ifade edilebilir.

Ayrıca Hz. Muhammed'i döneminin şartları içerisinde tanı(t)mak, onun hayatı ve tecrübelerini, sahip olduğu değerleri, günümüzdeki genç nesillere transfer edebilmek, özellikle de İslam toplumunda din-değer anlayışını ve bu süreçte gerçekleşen dönüşümü ortaya koymak açısından ulaştığı bulgular ve sonuçlar itibariyle araştırmanın alana katkı sağladığı söylenebilir.

\section{Kaynakça}

Abisel, N. (1999). Popüler sinema ve türler. Alan Yayınları.

Abisel, N. (2003). Sessiz sinema. Om Yayınevi.

Acuner, H. Y. (2005). Din eğitimi açısından 14-18 yaş arası gençlerde ahlaki yargı gelişimi (Samsun il örneği). Ondokuz Mayls Üniversitesi İlahiyat Fakültesi Dergisi, 18(19), 265-297. 
Aksu, A. B. (2004). Medya çocuk ve din eğitimi [Yayınlanmamış Doktora Tezi]. Uludağ Üniversitesi Sosyal Bilimler Enstitüsü.

Aktan, H. (1995). Emanet, Türkiye Diyanet Vakfi İslam Ansiklopedisi. (c. 11, ss. 83-84). TDV Yayınları.

Aktaş, C. (2015). Şark'ın şiiri İran sineması. İz Yayıncılık.

Aydın, M. Ş. (2017). Din eğitimi bilimi. Kimlik Yayınları.

Ayhan, H. (2014). Türkiye'de din eğitimi. Ensar Neşriyat.

Bahçekapıl1, M. (2011). Din ve ahlak eğitiminin ergenlerin kişilik gelişimine katkısı. Değerler Eğitimi Dergisi, 9(22), 7-42.

Bahçekapılı, M. vd. (Ed.) (2017). Din Eğitiminde Motivasyon ve Verimlilik. Balıkesir Büyükşehir Belediyesi Kültür Yayınları / Eğitim-1.

Balc1, A. (2006). Sosyal bilimlerde araştırma, yöntem, teknik ve ilkeler. Pegem A Yayıncılık.

Batur, S. (2005).Siyasal İslam sineması örneğinde Iran sineması [Yayınlanmış Doktora Tezi]. Dokuz Eylül Üniversitesi Sosyal Bilimler Enstitüsü.

Bazın, A. (2000). “Sinema nedir?”. İ. Şener (Çev.) İzdüşüm Yayınları

Bedir Erişti, S. D. (Ed.) (2018). Görsel araştırma yöntemleri teori, uygulama ve örnek. Pegem Akademi

Bilgin, B. (1990). Egitim bilimi ve din eğitimi. Ankara Üniversitesi Fakülte Yayınları.

Bozdağ, A. \& Yavuz C. (2019). Majid Majidi'nin Cennetin Rengi Filmindeki Çocuk Karakterlerin Sosyo-Kültürel Bağlamda İncelenmesi. International Social Sciences Studies Journal, 5(44), 4942-4958. http://dx.doi.org/10.26449/sssj.1728

Çağrıc1, M. (2000). Îsâr, Türkiye Diyanet Vakfi İslam Ansiklopedisi. (c. 22, ss. 490, 491). TDV Yayınlar1.

Doğan, R \& Ege, R. (Ed.). (2017). Din eğitimi el kitabı. Grafiker Yayınları.

Erdoğan, N. (1992). Sinema kitabı. Ağaç Yayıncılık.

Fraenkel, J. R. \& Wallen, N. E. (2009). How to Designing and Evaluate Research in Education. McGraw-Hill.

Furat, A. Z. (2008). Yetişkinlerin yaygın din eğitiminde televizyonun yeri ve fonksiyonları (İstanbul örneği) [Yayınlanmış Doktora Tezi]. İstanbul Üniversitesi Sosyal Bilimler Enstitüsü.

Güçhan, G. (1993). Sinema Toplum İlişkileri. Anadolu Üniversitesi İletişim Bilimleri Fakültesi Kurgu Dergisi, 12, 51-71.

Hökelekli, H. (2013a). Değerler psikolojisi ve eğitimi. Timaş Yayınları.

Hökelekli, H. (Ed.). (2015). Gençlik din ve değerler psikolojisi. DEM Yayınları.

Hökelekli, H. (2013b). Psikoloji, Din ve Eğitim Yönüyle İnsan Değerler. DEM Yayınları.

İnce, M. (1991). Çizgi filmlerin 6-18 yaş grubu bireylerin yaşantılarında yeri ve önemi [Yayınlanmamış Yüksek Lisans Tezi]. Gazi Üniversitesi Sosyal Bilimler Enstitüsü.

Kale, Ö. (2010). Edebiyat sinema ilişkisi. Uluslararası Sosyal Araştırmalar Dergisi, 3(14), 266-275.

Kara, İ. (2006). Dini Kavramlar Sözlüğ̈̈. DİB Yayınları. 


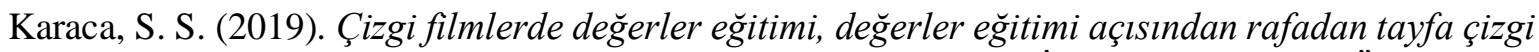
filminin incelenmesi [Yayınlanmamış Yüksek lisans Tezi]. İzmir Kâtip Çelebi Üniversitesi Sosyal Bilimler Enstitüsü.

Köylü, M. \& Altaş, N. (Ed.) (2014). Din eğitimi. Ensar Neşriyat.

Köylü, M. \& Oruç, C. (2017). Çocukluk dönemi din eğitimi. Nobel Yayınları.

Kur'ân-1 Kerîm ve Türkçe Anlamı (Meâl) (1983). H. Atay \& Y. Kutluay (Çev.) DİB Yayınları.

Lüleci, Y. (2007). Sinema ve din: Türk sineması örneği [Yayınlanmamış Yüksek Lisans Tezi]. Marmara Üniversitesi Sosyal Bilimler Enstitüsü.

Meydan, H. (2014). Okulda değerler eğitiminin yeri ve değerler eğitimi yaklaşımları üzerine bir değerlendirme. Bülent Ecevit Üniversitesi İlahiyat Fakültesi Dergisi, 1(1), 93-108.

Monaco, J. (2009). Bir film nasıl okunur? Sinema dili, tarihi ve kuramı. Oğlak Yayıncılık.

Nafisi, H. (2008). İran sineması, G. Nowell-Smith (Ed.) A. Fethi (Çev.) Dünya sinema tarihi. Kabalc1 Yayınevi.

Nafisi, H. (1995). İran'da İslamize film kültürü. E. Özen (Çev.) 25. Kare Sanat ve Kültür Dergisi, $18,58-69$.

Nowell-Smith, G. (2003). Dünya sinema tarihi. A. Fethi (Çev.) Kabalcı Yayınları.

Onaran, Â. Ş. (1986).Sinemaya giriş. Filiz Kitabevi.

Öcal, M. (1999). Din eğitimi ve ögretiminde metodlar, TDV Yayınları.

Özgökbel Bilis, P. (2011). Çizgi filmlerde temsil edilen toplumsal değerler sistemi [Yayımlanmamış Doktora Tezi]. Ege Üniversitesi Sosyal Bilimler Enstitüsü.

Özkan, U. B. (2019). Eğitim bilimleri araştırmaları için doküman inceleme yöntemi. Pegem Akademi.

Özön, N. (2008). Sinema sanatına giriş. Agora Kitaplığı.

Patton, M. Q. (2018). Nitel Araştırma ve Değerlendirme Yöntemleri. M. Bütün \& S. B. Demir (Çev. Ed.) Pegem Akademi Yayınc1lık.

Peker, H. (1998). Din ve ahlâk eğitimi. Aksi Seda Matbaası.

Râgıb el-İsfahânî, Ebü'l-Kāsım Hüseyn b. Muhammed b. el-Mufaddal. (1961). el-Müfredât fî garîbi'l-Kur'ân. M. S. Kîlânî (Nşr.).

Rotha, P. (1996). Sinema tarihi - ülke sinemaları. İ. Şener (Çev.) Sistem Yayıncılık.

Ryan, M. ve Kellner, D. (1997). Politik Kamera. E. Özsayar (Çev.) Ayrıntı Yayınları.

Sarmış, M. (2016). Sinema ve din (sekülerleşme bağlamında hollywood sineması örneği) [Yayınlanmamış Doktora Tezi]. Necmettin Erbakan Üniversitesi Sosyal Bilimler Enstitüsü.

Tapper, R. (2007). Yeni iran sinemast siyaset, temsil ve kimlik. Kap1 Yayınları.

Teksoy, R. (2014). Sinema tarihi. Oğlak Yayınları.

Tınaz Gürmez, P. (2006). Türk Sineması'nın ustalarından sinema dersleri. İnk1lap Kitabevi.

Toksarı, A. (1995). Emanet, Türkiye Diyanet Vakfi İslam Ansiklopedisi. (c. 11, ss. 81-83). İstanbul: TDV Yayınları.

Tosun, C. (2015). Din eğitimi bilimine giriş. Pegem Akademi. 
Türk, E. (2014). Çocukluk döneminde duygusal gelişim ve din eğitimi. Marife Dini Araştırmalar Dergisi, 14(3), 143-158.

Türkeri, A. (2019). Hz. Muhammed: Allah'in elçisi filmi örnekliğinde teopolitik söylem -sinemagerçeklik inşası [Yayınlanmış Yüksek lisans Tezi]. Akdeniz Üniversitesi Sosyal Bilimler Enstitüsü.

Ulusoy, K. \& Dilmaç, B. (2015). Değerler eğitimi. Pegem Akademi Yayınları.

Vincenti, G. (2008). Sinemanın yüzyılı”, E. Ayça (Çev.) Evrensel Basım Yayın.

Yaghmoorala, M. V. (2013). Majid Majidi'nin filmlerinde sosyal ve kültürel anlatı yapisl [Yayınlanmamış Yüksek Lisans Tezi]. Ege Üniversitesi Sosyal Bilimler Enstitüsü.

Yağl1, A. (2013). Çocuğun eğitiminde ve sosyal gelişiminde çizgi filmlerin rolü: Caillou ve Pepee örneği. Turkish Studies, 8(10), 707-719.

Yaren, Ö. (2002). Devrim sonrası Iran sineması Muhsin Mahmelbaf örneği [Yayınlanmamış Yüksek Lisans Tezi]. Ankara Üniversitesi Sosyal Bilimler Enstitüsü.

Yavuz, K. (1988). Günümüzde din eğitimi. Çukurova Üniversitesi İlahiyat Fakültesi Yayınları.

Yıldırım, A. \& Şimşek, H. (2004). Sosyal bilimlerde nitel araştırma yöntemleri. Seçkin Yayınları.

Yorulmaz, B. (2013a). Din ve değerler eğitimi açısından Caillou çizgi filminin değerlendirilmesi. Diyanet Ilmi Dergi, 49(3), 127-143.

Yorulmaz, B. (2013b). Pepee çizgi filminin din ve değerler eğitimi açısından değerlendirilmesi. Uluslararası Sosyal Araştırmalar Dergisi, 6(24), 438-448.

Yorulmaz, B. (2010). Sinema ve din [Doktora Tezi]. Marmara Üniversitesi Sosyal Bilimler Enstitüsü.

Yorulmaz, B. (2016). Sinema ve din eğitimi. DEM Yayınları.

\section{İnternet Kaynakları}

Alpsoy, S. (2012). En etkin 100. Michael H. Hart. https://www.resulullah.org/en-etkin-100-michaelh-hart (Erişim Tarihi: 21 Haziran 2019).

Başa, Ş. (2020). Doküman Analizi.

https://www.academia.edu/8519906/DOK\%C3\%9CMAN_ANAL\%C4\%B0Z\%C4\%B0_S

UNUM_ (Erişim Tarihi: 11 Nisan 2020).

Dora, Ç. (2020). Doküman analizi. https://prezi.com/lxghbx1bbtqr/dokuman-analizi/ (Erişim Tarihi: 05 Mayis 2020).

Genç, $\quad$ M. $\quad$ (t.y.). Batılılara doğru İslam'ı anlatacă̆ım!. https://www.populersinema.com/roportaj/batililara-dogru-islami-anlatacagim-9549.htm (Erişim Tarihi: 30 Temmuz 2019).

Hart, M. H. (t.y.). https://www.turkcewiki.org/wiki/Michael_H._Hart (Erişim Tarihi: 20 Haziran 2019).

https://kuran.diyanet.gov.tr/tefsir/M\%C3\%A2ide-suresi/677/8-ayet-tefsiri (Erişim Tarihi: 29 Ağustos 2019).

https://kuran.diyanet.gov.tr/tefsir/sure/105-fil-suresi (Erişim Tarihi: 28 Temmuz 2019).

https://tr.wikipedia.org/wiki/Muhammed:_Allah\%27\%C4\%B1n_El\%C3\%A7isi (Erişim Tarihi: 11 Nisan 2020). 
https://www.academia.edu/19689098/9-NITEL-ANALIZLER-ICERIK-VE-BETIMSEL-

ANALIZ (Erişim Tarihi: 15 Nisan 2020).

https://www.bbc.com/turkce/haberler-turkiye-37822507 (Erişim Tarihi: 11 Nisan 2020).

https://www.haberler.com/iranli-yonetmen-majidi-filmde-hz-muhammed-in-3695922-haberi/ (Erişim Tarihi: 20 Haziran 2019).

https://www.mehrnews.com/news/2516657/ فيلم-محمد-رسول_الله_از_آغاز-تا_امروز-جشّ-جهان-به_ايران_است (Erişim Tarihi: 30 Temmuz 2019).

https://www.sabah.com.tr/fotohaber/magazin/hz-muhammed-allahin-elcisi-filmine-gisede-buyukilgi (Erişim Tarihi: 11 Nisan 2020).

IMDB. (2015a). https://www.imdb.com/title/tt3921314/mediaviewer/rm1234064128 (Erişim Tarihi: 30 Temmuz 2019).

IMDB. (2015b). Hz. Muhammed: Allah'in elçisi (2015). https://www.imdb.com/title/tt3921314/?ref_=nv_sr_1?ref_=nv_sr_1 (Erişim Tarihi: 30 Temmuz 2019).

IMDB. (t.y.a). Hz. Muhammed: Allah'ın elçisi (2015). https://www.imdb.com/title/tt3921314/?ref_=nv_sr_1?ref_=nv_sr_1 (Erişim Tarihi: 28 Haziran 2019).

IMDB. (t.y.b). Majid $\quad$ Majidi. https://www.imdb.com/name/nm0006498/?ref_=nv_sr_1?ref_=nv_sr_1\#director (Erişim Tarihi: 28 Haziran 2019).

IMDB. (t.y.c). Majid $M a j i d i$. https://www.imdb.com/name/nm0006498/?ref_=nv_sr_1?ref_=nv_sr_1\#producer (Erişim Tarihi: 28 Haziran 2019).

IMDB. (t.y.d). Majid Majidi. https://www.imdb.com/name/nm0006498/?ref_=nv_sr_1?ref_=nv_sr_1\#writer (Erişim Tarihi: 28 Haziran 2019).

IMDB. (t.y.e). Majid Majidi biography. https://www.imdb.com/name/nm0006498/bio?ref_=nm_ov_bio_sm (Erişim Tarihi: 11 Nisan 2020).

İSAM. (2020). Ilahiyat makaleleri veri tabanı. http://ktp.isam.org.tr/?url=makaleilh/findrecords.php (Erişim Tarihi: 16 Nisan 2020).

Majidi, M. (2005). http://www.cineMejidi.com (Erişim Tarihi: 25 Haziran 2019).

YÖK. (2020). Tez merkezi. https://tez.yok.gov.tr/UlusalTezMerkezi/ (Erişim Tarihi: 02 Nisan 2020). 